\title{
Recent Updates on Mechanisms of Resistance to 5-Fluorouracil and Reversal Strategies in Colon Cancer Treatment
}

\author{
Shamin Azwar ${ }^{1}$, , Heng Fong Seow ${ }^{1}$, Maha Abdullah ${ }^{1}$, Mohd Faisal Jabar ${ }^{2}$ and Norhafizah Mohtarrudin ${ }^{1, *}$ \\ 1 Department of Pathology, Faculty of Medicine and Health Sciences, Universiti Putra Malaysia, \\ Serdang 43400, Malaysia; shamin.azwar@gmail.com (S.A.); shf@upm.edu.my (H.F.S.); \\ maha@upm.edu.my (M.A.) \\ 2 Department of Surgery, Faculty of Medicine and Health Sciences, Universiti Putra Malaysia, \\ Serdang 43400, Malaysia; faisal@upm.edu.my \\ * Correspondence: norhafizahm@upm.edu.my
}

check for

updates

Citation: Azwar, S.; Seow, H.F.; Abdullah, M.; Faisal Jabar, M.;

Mohtarrudin, N. Recent Updates on

Mechanisms of Resistance to

5-Fluorouracil and Reversal Strategies in Colon Cancer Treatment. Biology 2021, 10, 854. https://doi.org/ 10.3390/biology10090854

Academic Editor: Angabin Matin

Received: 9 July 2020

Accepted: 11 August 2020

Published: 31 August 2021

Publisher's Note: MDPI stays neutral with regard to jurisdictional claims in published maps and institutional affiliations.

Copyright: (C) 2021 by the authors. Licensee MDPI, Basel, Switzerland. This article is an open access article distributed under the terms and conditions of the Creative Commons Attribution (CC BY) license (https: / / creativecommons.org / licenses/by/4.0/).
Simple Summary: Acquired resistance to chemotherapy by cancer cells is the predominant factor in chemotherapy failure, which ultimately leads to disease progression and death. Recent studies have presented compelling evidence of the various mechanisms and pathways through which cancer cells have developed resistance to drugs. This review summarises the mechanisms pertaining to 5-FU resistance and discusses ongoing efforts to prevent chemotherapy resistance in cancer cells and to re-sensitise them to cancer drugs.

Abstract: 5-Fluorouracil (5-FU) plus leucovorin (LV) remain as the mainstay standard adjuvant chemotherapy treatment for early stage colon cancer, and the preferred first-line option for metastatic colon cancer patients in combination with oxaliplatin in FOLFOX, or irinotecan in FOLFIRI regimens. Despite treatment success to a certain extent, the incidence of chemotherapy failure attributed to chemotherapy resistance is still reported in many patients. This resistance, which can be defined by tumor tolerance against chemotherapy, either intrinsic or acquired, is primarily driven by the dysregulation of various components in distinct pathways. In recent years, it has been established that the incidence of 5-FU resistance, akin to multidrug resistance, can be attributed to the alterations in drug transport, evasion of apoptosis, changes in the cell cycle and DNA-damage repair machinery, regulation of autophagy, epithelial-to-mesenchymal transition, cancer stem cell involvement, tumor microenvironment interactions, miRNA dysregulations, epigenetic alterations, as well as redox imbalances. Certain resistance mechanisms that are 5-FU-specific have also been ascertained to include the upregulation of thymidylate synthase, dihydropyrimidine dehydrogenase, methylenetetrahydrofolate reductase, and the downregulation of thymidine phosphorylase. Indeed, the successful modulation of these mechanisms have been the game plan of numerous studies that had employed small molecule inhibitors, plant-based small molecules, and non-coding RNA regulators to effectively reverse 5-FU resistance in colon cancer cells. It is hoped that these studies would provide fundamental knowledge to further our understanding prior developing novel drugs in the near future that would synergistically work with 5-FU to potentiate its antitumor effects and improve the patient's overall survival.

Keywords: 5-fluorouracil; 5-FU; chemotherapy drug resistance; colon cancer; thymidylate synthase; thymidine phosphorylase; dihydropyrimidine dehydrogenase; methylenetetrahydrofolate reductase; overcoming chemotherapy drug resistance

\section{Introduction}

Colorectal cancer remains as the third leading cause of cancer-related mortality worldwide, with 1.8 million new patients diagnosed and 900,000 deaths reported annually [1]. Men are reported to be more susceptible to the disease, with 2.56 million cases reported 
in 2018 alone in comparison with the 2.19 million cases reported in women [2]. Most of these cases concern the elderly population, with $70 \%$ of cases occurring in individuals above 65 years of age [3]. Risk factors can either be attributed to environmental factors that include poor dietary habits, lack of physical activity, cigarette smoking, and alcohol consumption, or hereditary with pre-existing genetic predispositions.

Since its discovery in 1957, the infusional administration of 5-fluorouracil potentiated with leucovorin has been the mainstay preferred combinational chemotherapy option for solid tumors such as colorectal cancer as well as breast, stomach, and head and neck cancers $[4,5]$. For patients with advanced disease, 5-FU/LV combined with oxaliplatin (FOLFOX) or irinotecan (FOLFIRI) served as the first-line treatment with considerable improvement in patient's relapse rate (RR) and overall survival (OS) despite the added toxicity. Being a fluorinated analog of uracil, 5-FU exerts its cytotoxic effects through the inhibition of thymidylate synthase (TYMS) that subsequently impairs cellular DNA synthesis functions in tumor cells [5]. Fluorinated byproducts of 5-FU metabolisms, that include fluorouridine triphosphate (FUTP) and fluorodeoxyuridine triphosphate (FdUTP) may also be misincorporated into RNA and DNA of tumor cells to further disrupt protein translation and expression. To further minimize the risk of disease relapse, targeted therapy with the use of agents such as anti-EGFR cetuximab and anti-angiogenesis bevacizumab may be additionally prescribed for patients in advanced stages [6]. Despite best efforts, the reported response rate of 5-FU as a single agent treatment is still fairly limited at between $10-15 \%$. In comparison, the use of a FOLFOX or FOLFIRI regimen may see a significant improvement with reported objective response rate (ORR) of approximately 50\% [7,8]. For patients treated with 5-FU-based regimens, the 3- and 5-year survival rates are reported to be at $72.2 \%$ and $60 \%$, respectively $[9,10]$. However, considering that the first diagnoses of most patients are commonly of late presentations, it is alarming to note that the overall 5-year survival rate of these patients with advanced disease is still at a mere $18.3 \%$ [11]. It is thus crucial for more studies to be conducted to improve our best knowledge of the possible reasons behind 5-FU chemotherapy failure.

Chemotherapy failure that leads to disease progression and death is often the manifestation of chemotherapy resistance. Chemoresistance is defined by increased tumor cells tolerance against chemotherapy agents, as the pro-survival strategies against its directed cytotoxic effects. In this review, we will discuss new knowledge concerning the various mechanisms that may contribute to 5-FU resistance, particularly in colonic adenocarcinomas. These resistance mechanisms can be "classical", as it may also concern other antineoplastic agents in contributing to the incidence of multidrug resistance (MDR), or "5-FU-specific". We will also discuss recent approaches that are being investigated in the effort to enhance 5-FU sensitivity and overcome resistance.

\section{Mechanisms of Action of 5-Fluorouracil}

It was initially discovered that uracil is metabolized more rapidly than any other pyrimidine nucleotides in pre-neoplastic and hepatoma rats when compared to healthy rats [12]. The finding later encouraged a joint collaborative effort to synthesize a new class of antitumor compounds that could potentially exert its antitumor effects by targeting uracil metabolism in tumor cells [4]. The resulting compound is 5-FU as a heterocyclic compound with the structure almost identical to pyrimidine, but with a fluorine atom substituted from hydrogen at the C-5 position [13].

Following intravenous injection, only $1-5 \%$ of prodrug 5 -FU is metabolized into active cytotoxic metabolites with approximately $20 \%$ being subjected to urinal excretion while the remaining $80 \%$ is rapidly degraded in the liver [14]. Degradation of 5-FU is facilitated by the enzyme dihydropyrimidine dehydrogenase (DPD) that catabolizes the conversion of 5-FU into 5,6-dihydro-5-fluorouracil (DHFU) as the inactive metabolite [15]. The catabolism process then continues with the conversion of DHFU to $\alpha$-fluoro- $\beta$-ureidopropionic acid (FUPA) by dihydropyrimidinase (DPYS), and subsequently, its decarboxylation and deamination reactions to $\alpha$-fluoro- $\beta$-alanine (FBAL) by $\beta$-ureidopropionase (UPB1). Anabolic 
pathway begins with the rapid entry of 5-FU into cells via a similar transport mechanism as uracil prior its conversion to either substrate fluorouridine monophosphate (FUMP) or fluorodeoxyuridine (FdUR) (Figure 1). Conversion to FUMP is catalyzed by the enzyme orotate phosphoribosyltransferase (OPRT) in the presence of phosphoribosyl pyrophosphate (PRPP). FUMP is then phosphorylated to fluorouridine diphosphate (FUDP), prior to another phosphorylation process that converts it to either active metabolite FUTP or into fluorodeoxyuridine diphosphate (FdUDP) by the enzyme ribonucleotide reductase (RNR) [16]. Being a fluorinated analogue of RNA nucleotide, FUTP can be misincorporated into the RNA of tumor cells and cause RNA damage. Given the central role of RNAs in protein translation, the protein expression of 5-FU-treated cells tend to be severely disrupted that promote the activation of cellular autophagy and apoptosis machinery [17]. In the meantime, FdUDP is further phosphorylated to active metabolite FdUTP and is misincorporated into the DNA of tumor cells to alternatively cause DNA damage. Prodrug 5-FU conversion to FdUR is facilitated by the enzyme thymidine phosphorylase (TYMP) prior to further phosphorylation to active metabolite fluorodeoxyuridine monophosphate (FdUMP). FdUMP may then form a stable ternary complex with enzyme TYMS along with 5,10-methylenetetrahydrofolate $\left(\mathrm{CH}_{2} \mathrm{THF}\right)$ as a methyl donor to irreversibly inhibit the enzymatic activity of TYMS [18]. This in turn prevents the conversion of substrate deoxyuridine monophosphate (dUMP) to deoxythymidine monophosphate (dTMP) that results in deoxynucleotide pool imbalances, and ultimately, in the arrest of cellular de novo DNA synthesis and repair.

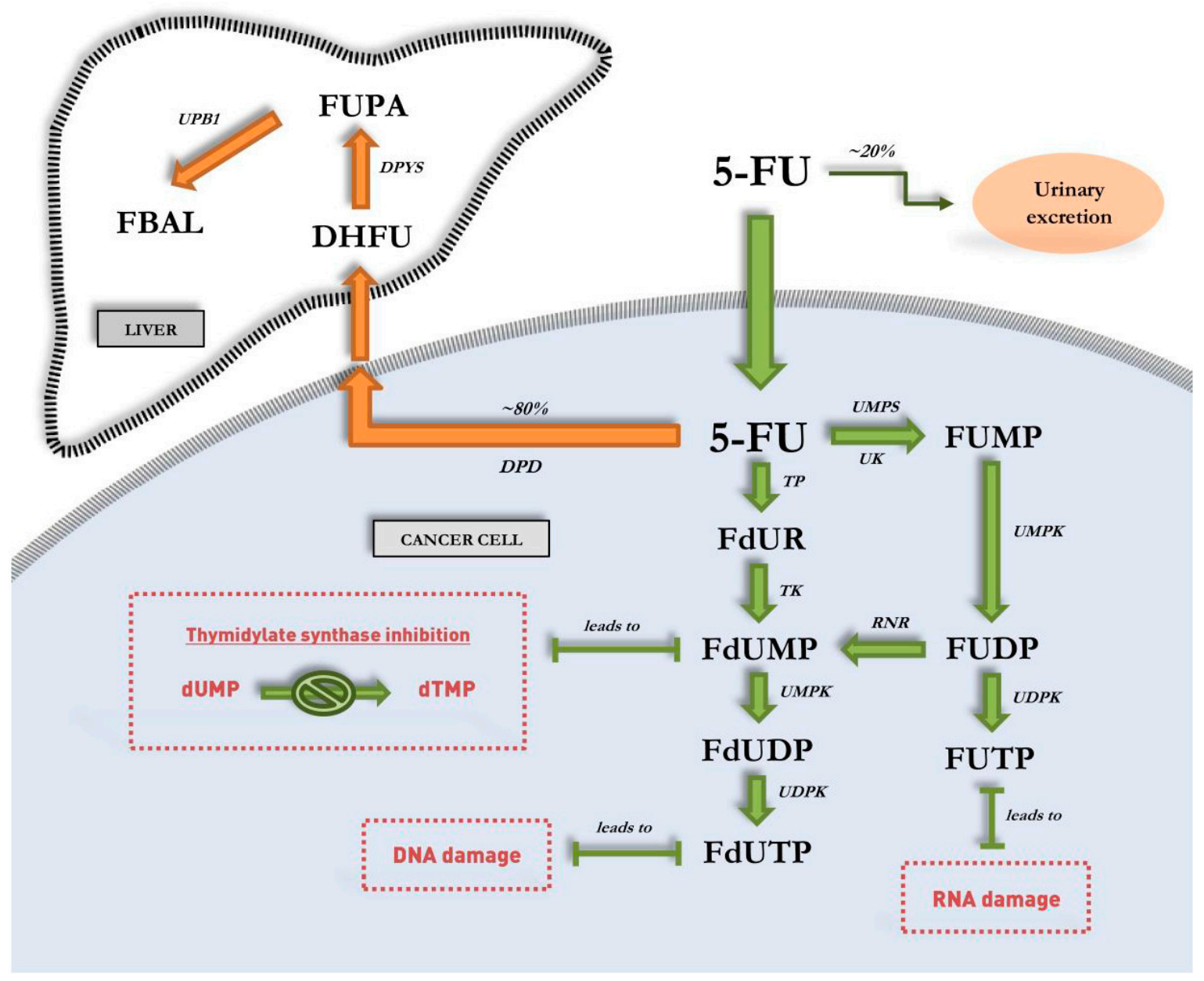

Figure 1. Various key enzymes facilitate the mechanism of action (anabolism) of 5-FU in cancer cells and its elimination (catabolism) via the hepatic system. 


\section{Classical Mechanisms of Resistance}

\subsection{Alterations in Drug Transports}

Figure 2 summarizes the mechanisms of 5-FU resistance in colon cancer. The increased rate of intracellular drug exports reduces drug bioavailability within cells and is considered a major factor in the development of multi-drug resistance. Drug exports are predominantly facilitated by ATP-hydrolyzing, unidirectional transmembrane efflux pumps, notably, the ATP-binding cassette (ABC) transporters [19]. Overexpression of ABC proteins, however, presents an unfavorable implication on the prognosis of colon cancer patients receiving 5-FU treatment with studies reporting both negative and positive correlations [20-23]. Nonetheless, incidence of 5-FU resistance is still consistently motivated by elevated levels of ABC transporters, that includes ABCB1 [P-glycoprotein (P-gp) or MDR1] [24,25]; ABCG2 [breast cancer resistance protein (BCRP)] [26,27]; ABCC1 [multidrug resistance-associated protein (MRP1)] [28,29]; ABCC3 [20], and ABCC2 [30]. Surprisingly, in one study, 5-FU resistance in colon cancer cells was instead attributed to the loss of $A B C B 4$ [31]. ABC transporters are substrate-specific that only conforms to structural changes upon binding with recognizable ligands facilitated by the hydrophobic transmembrane domain (TMD) [32] Meanwhile, the nucleotide-binding domain (NBD), harnesses energy from ATP hydrolysis to allow these substrates to translocate across the cellular membrane. Studies that aim to explore the upstream influencers of $A B C$ transporters remain scarce. It was determined that the transcription factor hairy and enhancer of split-1 (HES1) regulates the expression of $A B C C 1$ and $A B C C 2$ [30]. In other studies, $A B C B 1, A B C C 1$, and $A B C G 2$ overexpression were found induced by not only transcription factor X-box binding protein (XBP1) but together with inositol-requiring enzyme $1 \alpha$ (IRE1 $\alpha$ ), an endoplasmic-reticulum-localized protein that is activated upon endoplasmic reticulum stress [25]. CDK2-associated cullin domain 1 (CAC1) and antisense non-coding RNA (ncRNA) in the INK4 locus (ANRIL) influence on $\mathrm{ABCB} 1$ and $\mathrm{ABCC} 1$ were also demonstrated in recent studies, with ANRIL promoting their bindings with Let-7a microRNA (miRNA) precursor $[27,33]$.

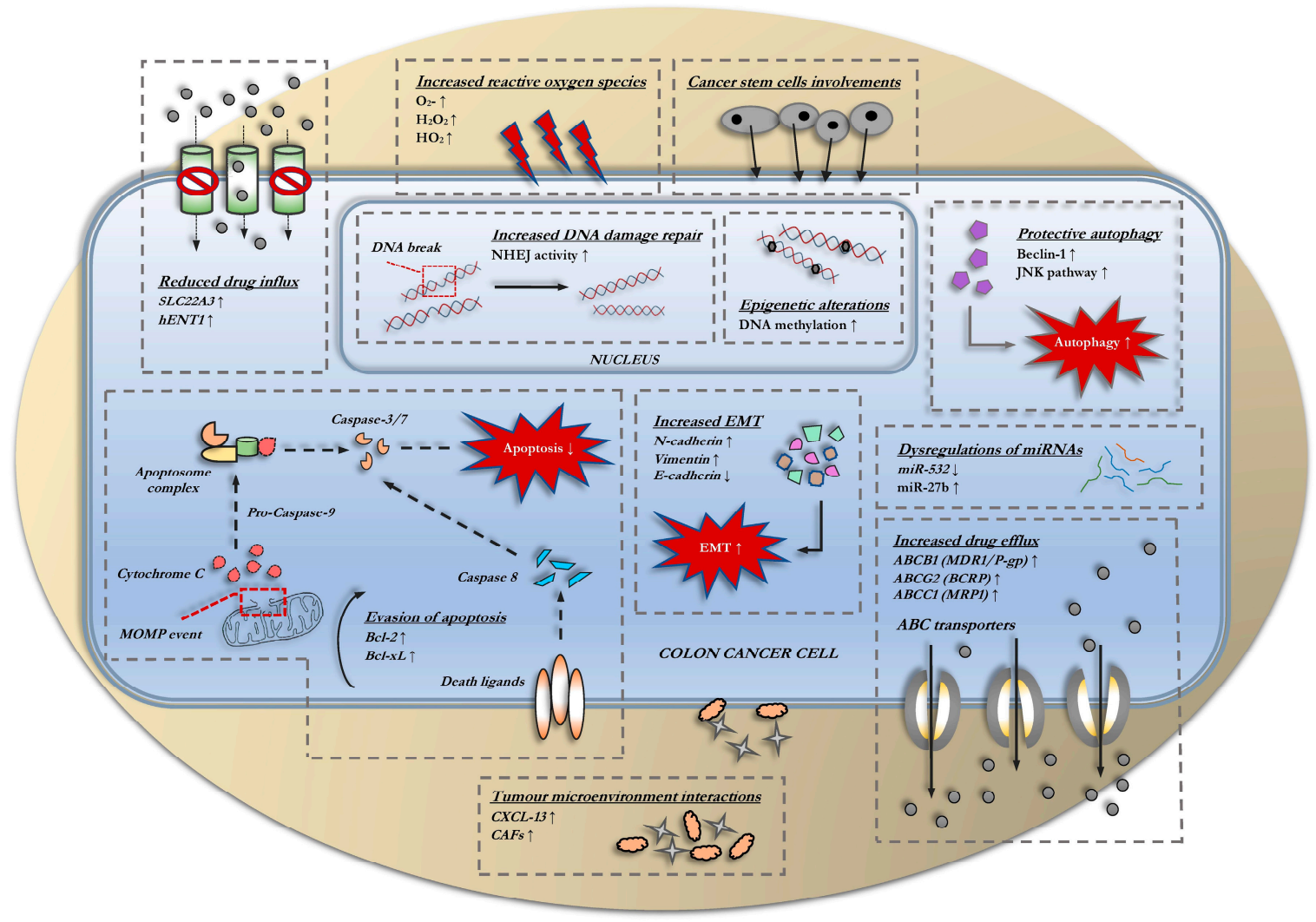

Figure 2. Recent discoveries on the classical drug resistance mechanisms involving 5-FU resistance in colon cancer cells. 
In addition to drug export, reduced drug accumulation within resistant cells may also be the outcome of decreased drug uptake. Unlike ATP-mediated drug efflux, the mechanism of drug influx into tumor cells can simply be via passive diffusion and is facilitated by a group of proteins belonging to the solute carrier (SLC) transporter superfamily [34]. The entry of 5-FU as an analogue of nucleoside is primarily facilitated by the SLC28 family, or also known as the "concentrative nucleoside transporters" (CNTs), and the SLC29 family, or also known as the "equilibrative nucleoside transporters" (ENTs) [35,36]. To the best of our knowledge, only one study had been conducted to investigate the link between these nucleoside transporters with 5-FU chemoresistance in colon cancer. It was concluded that high human ENT 1 (hENT1) level in tumor tissue is correlated with poor clinical response to 5-FU, supported by in vitro findings [37]. Similar findings were later observed in studies concerning pancreatic cancer, whereby, overexpression of hENT1 were associated with lower 5-FU chemosensitivity [38]. Surprisingly, the expression of SLCs such as SLC37A1, SLC22A3, and SLC39A7 were raised in tumors of colon cancer patients and are associated with poor patient prognosis and disease progression [39-41]. Higher SLC expression may have allowed for enhanced nutrient intake to support accelerated tumor growth.

\subsection{Evasion of Apoptosis}

Apoptosis or programmed cell death is a regulated form of cell death triggered upon exposure to irreversible damage or upon cellular senescence. In tumorigenesis, apoptosis is suppressed in an orchestrated manner through upregulations of anti-apoptotic proteins B-cell lymphoma 2 (Bcl-2), B-cell lymphoma-extra large (Bcl-xL), B-cell lymphoma$\mathrm{w}(\mathrm{Bcl}-\mathrm{W})$, and induced myeloid leukaemia cell differentiation protein (Mcl-1), and the downregulation of pro-apoptotic proteins Bcl-2 associated $\mathrm{X}$ protein (Bax), Bcl-2 interacting protein (Bim), Bcl-2 homologous antagonist/killer (Bak), BH3-interacting domain death agonist (Bid), and NOXA in the intrinsic mitochondrial apoptotic pathway to promote sustained tumor growth [42-46]. The equilibrium between these pro-apoptotic and antiapoptotic proteins modulate the gateway of apoptosis and is implicated in drug resistance. Resistance to 5-FU typically involves the activation of nuclear factor kappa-light-chainenhancer of activated $\mathrm{B}$ cells with signal transducer and activator of transcription 3 (NF$\mathrm{KB} / \mathrm{STAT} 3$ ) signaling pathway that not only promote the expression of anti-apoptotic Bcl-2, $\mathrm{X}$-linked inhibitor of apoptosis (XIAP), and inhibitor of apoptosis protein (IAP) survivin, but also the expression of anti-proliferative proteins cyclin D1, vascular endothelial growth factor (VEGF), and c-Myc [47-49]. These 5-FU-resistant cells exhibited higher levels of Bcl-2, Bcl-xL, Mcl-1, and XIAP expression by which re-sensitization to 5-FU has been achieved through its inhibition which subsequently promotes the upregulation of Bax and Bcl2associated agonist of cell death (Bad) expression [11,50]. Mechanistically, the activation of Bcl-2 and Bcl-xL expression drive constant retrotranslocation of pro-apoptotic proteins Bax and Bak away from the mitochondria into the cytosol to prevent its oligomerization that may result in mitochondrial outer membrane permeabilization (MOMP) [51]. MOMP event will release cytochrome $\mathrm{C}$ from the mitochondria into the cytosol and trigger a cascade of caspase-mediated apoptosis involving pro-caspase-9, and executioner caspase- $3 / 7$. Accordingly, pro-apoptotic BAX expression was suppressed in resistant cells [52]. Recent studies have also associated phosphoinositide 3-kinases with protein kinase B (PI3K/AKT) signaling pathway activation with upregulation of Bcl-2 and caspase-3, together with the downregulation of Bax and cleaved-caspase- 3 with decreased tumor cell sensitivity towards 5-FU cytotoxicity [53]. Interestingly, these pathways may have been triggered concurrently as demonstrated in 5-FU-resistant LS174 colon cancer cells with the activations of JAK/STAT3, MAPK, PI3K/AKT, and NK-KB signaling pathways altogether [28]. Bcl2 related ovarian killer (BOK) is another pro-apoptotic protein that has been recentlycharacterized. In their studies, Srivastava and colleagues (2019) had reported BOK to be a positive regulator of uridine monophosphate synthase (UMPS) in the metabolism of 5-FU, and that BOK inhibition had resulted in decreased tumor cell sensitivity towards 5-FU 
treatment [54]. Accordingly, patients receiving 5-FU therapy observed diminishing levels of BOK protein, suggesting a feedback mechanism triggered by tumor cells for survival.

Resistance may also be mediated through the extrinsic apoptosis pathway that triggers cascading caspase activation via cell-surface death receptors. The extrinsic pathway is pro-caspase-8-dependent, and its regulations in colon cancer involve the p53-mediated activation of death factors such as Fas and tumor necrosis factor alpha (TNF- $\alpha$ ) [55]. Tumor cell tolerance against chemotherapeutic agents is usually the consequence of intrinsic pathway activation rather than extrinsic, albeit certain studies have demonstrated otherwise [56,57]. In a study, decreased expression of Fas, Fas ligand (FasL), and pro-caspase-8 were determined in colon cancer cells upon 5-FU treatment, suggesting the promotion of resistance through the extrinsic pathway [58]. Indeed, reduced levels of Fas and pro-caspase-8 were observed in 5-FU-resistant colon cancer cells [59,60]. Interactions by binding between Fas and FasL allow the recruit of adaptor protein Fas-associated death domain (FADD) that triggers the activation of pro-caspase- 8 , and subsequently, executioner caspase- $3 / 7$ that initiates the apoptosis process. Interestingly, Fas/FasL dysregulation also allows tumor cells to remain unrecognized by Fas ${ }^{+}$lymphocytes and evade immune response [61]. Diminishing Fas expression coupled with $\mathrm{CD} 133^{+} \mathrm{CD} 24^{\text {lo }}$ tumor cells phenotype is correlated with decreased survival of colon cancer patients [62].

\subsection{Changes in Cell Cycle and DNA-Damage Repair Kinetics}

In eukaryotic cells, cellular proliferation and division can be divided into five wellcharacterized phases; $\mathrm{G}_{0}$ (cellular quiescence), $\mathrm{G}_{1}$ (physical and organelles developments), $\mathrm{S}$ (DNA synthesis), $\mathrm{G}_{2}$ (protein expression production), and $\mathrm{M}$ (mitotic division) [63]. The transition between phases is coordinated by oscillating levels of cyclins and cyclindependent kinases (CDKs) that act as "molecular checkpoints" responsible for the maintenance of genomic integrity and stability throughout the cell cycle. It is established that 5-FU exerts its cytotoxic effects in tumor cells primarily through inhibition of DNA synthesis. This is evident in the significant arrests of $G_{1} / S$ and $S$ phases of cell cycle, as well as reduced $\mathrm{G}_{2} / \mathrm{M}$ phase population in colon cancer cells post-5-FU treatment $[28,64]$. 5-FU-resistant cells typically exhibit attenuated effects of 5-FU cytotoxicity with a higher population of cells detected in both $\mathrm{G}_{1} / \mathrm{S}$ and $\mathrm{S}$ phases when compared to $5-\mathrm{FU}$-susceptible cells $[27,28,65,66]$. When DNA synthesis remains unimpaired, 5-FU-resistant cells may also observe a higher population of $\mathrm{G}_{2}$ phase cells when compared to 5-FU-susceptible cells [26]. Prolonged $G_{1}$ and $S$ phases may provide sufficient time for tumor cells to counteract against 5-FU-induced DNA damage through activation of DNA repair pathways.

Progression of cell cycle is generally dependent on the absence or presence of DNAdamage response (DDR). It is especially pertinent in 5-FU treatment whereby FdUTP misincorporation into DNA bases may trigger base excision repair (BER) and the mismatch repair (MMR) pathways activation to excise false nucleotides from sequences. This in turn collapses the DNA replication forks to induce lesions that are described as double-stranded DNA break (DSB) resulting in DDR [67]. Two major pathways for DSB repair have been characterized, namely, the homologous recombination (HR) and the non-homologous end-joining (NHEJ) pathways. NHEJ typically serves as the major DSB repair pathway that is presented in all cycle stages, while HR functions are only limited to the late $S$ and $\mathrm{G}_{2}$ phases of the cell cycle [68]. Inhibition of HR via targeting Rad51, an essential protein for DSB repair, led to an enhancement of 5-FU response [69].

In 5-FU-resistant cells, NHEJ activities are reported to be higher via the upregulation of its mediators that ultimately contribute to increased DNA damage repair and resistance to apoptosis $[70,71]$. These responses, nonetheless, are orchestrated by members of the PI3K family, namely, ataxia-telangiectasia mutated (ATM) and ATM- and Rad-related (ATR) kinases [72]. These kinases facilitate the recruitment of repair mediators into the DNA-damaged sites while stalling cell cycle progression in $\mathrm{G}_{1}, \mathrm{~S}$, or $\mathrm{G}_{2}$ phases through the activation effector checkpoint kinase (Chk1 and Chk2). It has been demonstrated that DNA damage invoked by 5-FU treatment activates ATM/ATR-mediated Chk1/Chk2 
upregulation that leads towards $\mathrm{S}$ and $\mathrm{G}_{2} \mathrm{M}$ phases cell cycle arrest, respectively, and ultimately in cellular apoptosis [73-76]. Conversely, the absence of ATM/ATR-mediated Chk1/Chk2 activations is observed in 5-FU-resistant that hinders apoptosis.

\subsection{Involvement of Autophagy}

When under metabolic or replication stress, tumor cells may also undergo autophagy that sequesters damaged organelles or proteins into lysosomes for degradation as the protective catabolic mechanism to prevent further cellular damage and to maintain cellular homeostasis [77]. Replication stress that is induced by 5-FU therapy typically reflects in pro-survival autophagy response in 5-FU-resistant cells marked by increased activations of Beclin-1 and microtubule-associated proteins 1A/1B light chain 3B II (LC3-II) expression, following mammalian target of rapamycin (mTOR) pathway activation [78-80]. Beclin-1 facilitates the formation of LC3-II autophagosome from LC3-I that interacts with phosphatidylethanolamine (PE), autophagy-related genes 3 (Atg3), and Atg7 to allow for binding and degradation of erroneous substrates induced by 5-FU treatment [77]. Interestingly, there are growing number of studies that had attribute 5-FU resistance with autophagy inhibition instead [81-84]. It is due to these contraindicatory data that the therapeutic potential of autophagy modulation is still a subject of ongoing debates as autophagy involvement can be both pro-survival and pro-death. It is postulated that autophagy inhibition serves as the protective mechanism for resistant cells to avoid autophagic cell death [85].

\subsection{Epithelial-to-Mesenchymal Transition (EMT)}

A hallmark of cancer progression and metastasis is the increased capability of cancer cells to migrate and invade neighboring and distant tissues. This is commonly achieved following a morphogenetic process termed as epithelial-to-mesenchymal transition (EMT) in which epithelial cells losses its epithelial traits and acquire mesenchymal properties through cytoskeleton remodeling [86]. EMT is not only a well-known risk factor that is associated with tumor metastasis in the liver of colon cancer patients that leads to poor patient prognosis but is also associated with poor treatment response [87-90]. Over the years, growing literature has demonstrated the link between EMT events and 5-FU resistance as higher and reduced expression of mesenchymal and epithelial markers, respectively, were consistently reported in 5-FU-resistant cells. In these studies, levels of vimentin, zinc finger protein SNAI1 (SNAIL), phosphorylated nuclear factor NF- $\mathrm{kB}$ p65 subunit (p-p65), ten-eleven translocation methylcytosine dioxygenase 1 (TET1), and naked cuticle 2 (NKD2) were found to be significantly upregulated [48,91,92]. In contrast, the expression of E-cadherin, $\beta$-catenin, transcription factor 4 (TCF4), and Axin were downregulated. The transition can be mediated through several signaling pathways that include NF- $\mathrm{kB}$, Wnt, and Akt following stimulation from transcription factors [e.g., twistrelated protein 1 (TWIST1) and zinc finger E-box-binding homeobox 2 (ZEB2)], non-coding RNAs [e.g., metastasis-associated lung adenocarcinoma transcript 1 (MALAT1), SLC25A25AS1, and miR-23b), and epigenetic alterations (e.g., promoter methylation of TWIST1/2, ZEB2, and SNAI1/2) [93-98]. Interestingly, the activations of these EMT factors may also influence the regulation of other resistance mechanisms. For instance, the overexpression of SNAIL has been demonstrated to be capable of upregulating the expression of $A B C$ transporter, $\mathrm{ABCB} 1$, to promote resistance [24]. Other studies have also reported increased stemness of tumor cells following the activation of EMT factors TWIST1 and ZEB2 [98,99].

\subsection{Involvement of Cancer Stem Cells}

Cancer stem cells (CSCs), also known as "tumor-initiating cells", are a small subpopulation of cancer cells within tumors that have attained stem cell-like characteristics such as self-renewal and multi-directional differentiation capabilities [100]. There is growing evidence demonstrating the pivotal role of CSCs in tumor initiation, progression, metastases, and cancer recurrence, aside from contributing to intra-tumor heterogeneity [101-104]. 
CSCs are poorly differentiated in nature and possess the ability to remain quiescent in the $\mathrm{G}_{0}$ phase of the cell cycle, thus, helping them to escape from chemotherapy insults, which typically targets highly-proliferating and mature cancer cells [105]. Recent studies have also demonstrated the ready capability of CSCs to promote EMT via transcription factor ZEB2 even when untreated [99]. Furthermore, colon CSCs when under chemotherapy stress, may directly prompt the activation of other resistance pathways. These include raised Bcl-2 and $\mathrm{Bcl}-\mathrm{xL}$ that inhibit apoptosis [106,107]; higher expression of $\mathrm{ABC}$ transporters such as $\mathrm{ABCC} 2, \mathrm{ABCC} 3$, and ABCG2 that promote drug export from the cell [20,108]; overexpression of DNA repair gene $\mathrm{O}^{6}$-methylguanine-DNA-methyltransferase (MGMT) [109,110]; and the alteration of cell cycle checkpoint via phosphorylation of ATM, Chk1, and Chk2 proteins [111]. Akin to other 5-FU-resistant colon cancer cells, colon CSCs may also promote 5-FU resistance within the tumor microenvironment via the activation of PI3K/AKT signaling pathway that regulates cell growth and apoptosis [112,113]. Wnt signaling also plays a critical role in mediating drug resistance in CSCs as p300/ $\beta$-catenin binding has been shown to promote differentiation while CREB-binding protein/ $\beta$-catenin binding is necessary for potency maintenance of CSCs $[114,115]$. The knockdown of $\beta$-catenin may not only result in increased drug sensitivity through diminishing levels of CSCs' stemness but also in the inhibition of EMT activities [116].

Indication on the plausible involvement of colon CSCs to 5-FU resistance was first implied when isolated colon cancer cells presented with colon CSCs marker CD133 showed increased resistance towards apoptosis following 5-FU exposure when compared to CD133cells [117]. Indeed, as demonstrated in recent studies, these $\mathrm{CD} 133^{+}$together with $\mathrm{CD} 44^{+}$ cells do exhibit CSC-like phenotypes with increased viability, colony formation, migration, and invasion rates, alongside resistance towards apoptosis $[104,118,119]$. Interestingly, it has been shown that only a small subset of $\mathrm{CD} 133^{+}$cells is implicated with 5-FU resistance,

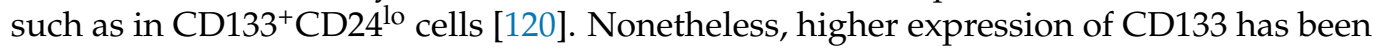
correlated with poor prognosis in stage II and III colon cancer patients [121,122]. In contrast, a higher level of CD44 presents an increase in risk for colon cancer as well as a worse overall survival of patients [123-125]. Aside from CD133, CD44, and CD24, the knockdown of other putative colon CSCs stemness such as aldehyde dehydrogenase (ALDH1) [126] and CD166 [127,128] have also exhibited increased cellular 5-FU-mediated cytotoxicity.

CSCs are also a major determining factor that contribute towards intra-tumoral heterogeneity. In theory, it is postulated that CSCs are placed at the apex of the division hierarchy, capable of undergoing both symmetric and asymmetric divisions that may differentiate into different types of cancer cells when triggered by environmental stimuli [129]. This results in a phenomenon known as clonal evolution, by which a single tumor may feature distinctive subpopulation of tumor cells carrying a wide range of genetic variation. 5-FU therapy is an example of an environmental stimulus that may drive tumor evolution. In one study, it was shown that 5-FU treatment promotes $\mathrm{T}>\mathrm{G}$ mutation in human small intestinal organoids cultures, causing subsequent 5-FU treatment to become less cytotoxic [7]. The mutation is perhaps a pro-survival feedback mechanism for the tumor cells to adapt to the cytotoxic environment. To make things more complicated, clonal variation also accounts for tumor protein 53 (p53) mutational status in patients that have likewise been shown to influence 5-FU chemosensitivity [130].

\subsection{Interactions within the Tumor Microenvironment}

Almost all mammalian cells, including tumor cells, are in constant communication with their respective microenvironment for the maintenance of cellular homeostasis and general survival [131]. For tumor cells, its interaction with its tumor microenvironment (TME) such as with supporting extracellular matrix (ECM) [132,133]; neighboring stromal cells which include cancer-associated fibroblasts (CAFs) [134], mesenchymal stem cells (MSCs) [135], and blood and lymphatic networks [136,137]; together with immune cells such as tumor-associated macrophages (TAMs) [138,139], natural killer cells (NK cells) $[140,141]$, and T/B lymphocytes [142-144] have been the highlights of many re- 
searchers due to its fundamental role in colon cancer progression and metastasis. The significance of TME in mediating 5-FU drug resistance has also gained attention in recent years due to its crosstalk influence on tumor cell behavior. For instance, in one study, chemokine C-X-C motif ligand 13 (CXCL-13) is found highly-expressed in the TME of 5-FU-resistant colon cancer cells as well as in sera of 5-FU-resistant patients associated with worse clinical outcome [145]. Although the mechanism as to how CXCL-13 participates in 5-FU resistance was not stated, it is highly plausible that resistance is achieved through piggybacking the same pathways responsible in promoting tumor growth, migration, and invasion in CXCR5-expressing colon cancer cells; through the activation of $\mathrm{PI} 3 \mathrm{~K} / \mathrm{AKT} / \mathrm{mTOR}$ and Wnt/ $\beta$-catenin signaling pathways [112,146,147]. Nonetheless, it was shown that CXCR-5 knockout mice exhibited an increased number of infiltrating B-cells that had contributed towards improved drug response. Meanwhile, a direct connection between CXCL12/CXCR4 axis and Wnt/ $\beta$-catenin signaling in enhancing 5-FU resistance can be observed in other studies [148-150]. CXCL-13 and CXCL-12, as chemokines, may also recruit T-regulatory cells into the microenvironment that would aid in 5-FU tolerance. This is evident in the CCL20/CCR6 axis as its overexpression in resistant patients has been associated with increased TFCD4 ${ }^{+}$infiltration from tumor-infiltrating lymphocytes (TILs) via forkhead box protein O1 (FOXO1)/CEBPB/NF-KB pathway [151]. Secreted transforming growth factor beta (TGF- $\beta$ ) may further facilitate resistance by prompting SMAD3 nuclear translocation that promotes neovascularization [152]. A higher level of TGF- $\beta$ may also promote TAMs polarization, specifically by M2 macrophages that secrete CCL22 to confer 5-FU resistance via the PI3K/AKT pathway [153,154]. Paradoxically, improved disease-free survival is observed in stage III colon cancer patients expressing a high level of M1 macrophages, suggesting a synergistic effect through immunogenic death with 5-FU via TNF $\alpha$ /TRAIL [155].

Tumor cells also interact with other stroma cells, such as with CAFs that actively partake in ECM deposition and remodeling despite their dual-role as both pro-tumorigenic and tumor-suppressive [156]. Aside from recruiting TAMs, transformed CAFs may secrete cytokines such as IL-6, IL-8, IL-17, TNF- $\alpha$, and VEGF that does not only contribute towards tumor aggressiveness but also in therapy response such as in 5-FU treatment [157-159]. Based on in vitro data, survival advantage gained can be attributed to AKT, mitogen-activated protein kinases 14 (P38), and Survivin nuclear translocation; elevated expression of CD44, $\beta$-catenin, leucine-rich repeat-containing $G$ protein-coupled receptor 5 (LGR5), and ABCG2; STAT3 augmentation; alongside PI3K/AKT and Janus kinase (JAK)/STAT pathways activation. CAFs may also promote tumorigenesis and 5-FU resistance through generating CSCs, resulting in a plethora of resistance pathways previously discussed $[158,160]$. While CAFs appear as an excellent target for anticancer drugs, conflicting data have also been presented in recent years that strongly suggest its role as a tumor suppressor [161,162].

As a molecular vehicle that exports a selective repertoire of DNA, RNA, proteins, lipids, and metabolites from one cell to another, the role that exosomes as extracellular vesicles play in mediating communication between tumor and stroma cells is undeniably extensive. In recent years, circulating exosomes have been demonstrated to mediate 5-FU resistance through the transfer of CAFs secretomes [163], transcription factor phosphorylated STAT3 (p-STAT3) [164], glycoprotein Wnt [165], circular RNAs circ_0000338 [166], as well as microRNAs such as miR-210 [167], miR-21 [168], and miR-145 [169]. Furthermore, exosomal marker tumor-associated glycoprotein 72 (TAG72) have been correlated with 5-FU-resistant patients, indicating its prognostic potential as a novel, non-invasive evaluation tool to predict patient's response to 5-FU-based therapy [170].

\subsection{Epigenetic Alterations}

Epigenetic modification refers to the heritable changes that do not directly affect the DNA sequence per se, but rather its accessibility and chromatin structure, attributed to incidences of DNA methylation and histone modifications that lead to the dysregulation of gene expression [171]. In colon cancer, dysregulation that elicits genomic instability 
causing tumor initiation can derive from gene promoter $\mathrm{CpG}$ island methylation as observed in tumor-suppressors Krüeppel-like factor 6 (KLF6), KLF4, and zinc finger protein 726 (ZNF726) silencing; through direct hypermethylation of one allele demonstrated in human mutL homolog 1 (hMLH1) and cyclin-dependent kinase inhibitor 2A (CDKN2A); and through DNA hypomethylation such as in the case of LINC00460 that promotes metastasis [172-175].

Certain methylation processes may also contribute to incidence of 5-FU resistance, aside from tumor progression. It was shown that protocadherin-17 (PCDH17) silencing via promoter methylation does not only suppresses its role as a tumor-suppressor in inducing apoptosis, but also in inducing JNK-dependent autophagic cell death upon 5-FU treatment in colon cancer [83]. Higher expression of PCDH17 is thus correlated with better OS of 5-FU-treated patients. In one study, integrated analysis of methylation profiling and protein-protein interaction (PPI) revealed that 5-FU resistance conferred through promoter hypermethylation can be a multitude, ranging from the involvement of p53 and epidermal growth factor receptor (EGFR) signaling pathways (e.g., EGFR and IGFBP3), drug metabolism through cytochrome P450 [e.g., cytochrome P450 3A5 (CYP3A5) and glutathione S-transferase P (GSTP1)], as well as in pyrimidine metabolism [e.g., cytidine deaminase (CDA)] [176]. Compelling evidence has been presented that linked miR-181a/135a/302c promoter hypermethylation, 5-FU tolerance, and microsatellite instability/microsatellite stable (MSI/MSS) status in colon cancer cells. In their studies, Shi and colleagues (2018) had demonstrated significant CPG island hypermethylation in promoter regions of miR-181a/135a/302c in cancer tissues of MSI patients when compared to MSS patients [177]. Interestingly, demethylation in vitro exerted reinforced 5-FU sensitivity in MSI phenotypic cells via targeting pleiomorphic adenoma gene 1 (PLAG1). Although most studies have reported negative correlations between gene hyper-/hypo-methylation and poor patient prognosis through resistance, such as in BCL2/adenovirus E1B $19 \mathrm{kDa}$ protein-interacting protein 3 (BNIP3) facilitated by DNA methyltransferase 1 (DNMT1) enzyme [178]; miR-26b via P-gp down-regulation [179]; DNMT3A and DNMT3B overexpression [180]; CCNE1, cyclin D1 binding protein 1 (CCNDBP1), paraoxonase 3 (PON3), as well as DEAD-box helicase 43 (DDX43) and cell adhesion molecule L1-like I (CHL1) via the mitogen-activated protein kinase (MAPK) apoptosis and PI3K/AKT proliferation pathways, respectively [181]; and osteopontin splicing isoform c via methyl-CpG binding protein 2 (MeCP2) [182], there are studies that had reported otherwise; WNT5A [183]; and NME/NM23 nucleoside diphosphate kinase 2 (NME2) [184]. Histone modifications are another common cause for epigenetic alterations and can be observed in the histone methylation H3K9me9 dysregulation and H3K27 PCAF-mediated histone acetylation of p53 $[66,185]$. Histone deacetylases are essential enzymes required for the reversible acetylation of histone. Its degradation via deubiquitinase USP38, specifically by histone deacetylase 3 (HDAC3), is also implicated in 5-FU resistance as epigenetic regulation via H3K27 acetylation is implied [186].

\subsection{Dysregulations of miRNAs}

MiRNAs are small, non-coding RNA molecules that have been implicated in various biological processes including colon tumorigenesis due to its capability to regulate gene expression post-transcriptionally via base-pairing with complementary mRNA. These micRNAs include miR-20a, $-182,-122,-425-5 p,-221,-200$, and -215-3p, that amongst others, target TGF- $\beta$, nucleic acid-binding protein 1 (NABP1), fructose-biphosphate aldolase (ALDOA), FOXO, quaking homolog, KH domain RNA binding (QKI), Ras association domain family member 2 (RASSF2), and forkhead box M1 (FOXM1) to influence tumor cell proliferation, migration and invasion, apoptosis, cell cycle, as well as DNA-damage repair [187-193]. A plethora of miRNA species that regulates tumor cell response towards 5-FU in colon cancer have also been described over the years (Table 1). MiR-532, for instance, may bind directly to the $3^{\prime}$ UTR regions of ETS proto-oncogene 1 (ETS1) and transglutaminase 2 (TGM2) to suppress its expression and inhibit further Wnt/ $\beta$-catenin 
signaling activation [194]. When factoring in p53 activation that is also induced by miR532-3p, significant restoration in 5-FU sensitivity can be observed attributed to increased cell cycle arrest and early apoptosis. Bioinformatic analysis revealed miR-494 to be correlated with 5-FU resistance through DNA topoisomerase IIA (TOP2 $\alpha$ ) overexpression [195]. Although the mechanism of resistance was not stated, the role of TOP $2 \alpha$ that maintains the topological status of chromosome during DNA replication and transcription may have facilitated enhanced tumor cell proliferation and DNA-damage repair in 5-FU-resistant cells [196].

Table 1. MiRNAs that mediate 5-FU resistance in colon cancer cells through the modulation of various pathways.

\begin{tabular}{cccc}
\hline miRNA & Resistance Expression & Mechanism & Ref \\
\hline miR-361 & Underexpressed & Upregulation of ABCC10/5 expression regulated by FOXM1 & {$[197]$} \\
miR-27a & Overexpressed & Modulation of DPYD expression & {$[198]$} \\
miR-200c & Underexpressed & Enhanced Bcl-2 expression & {$[199]$} \\
miR-587 & Overexpressed & Downregulation of PPP2R1B expression that increases AKT & {$[200]$} \\
miR-22 & Underexpressed & phosphorylation and XIAP expression & {$[201]$} \\
miR-224 & Underexpressed & Promotes autophagy via BTG1 upregulation & {$[94]$} \\
miR-375 & Underexpressed & Suppressed apoptosis via repressed E2F activity & {$[202]$} \\
miR-31 & Overexpressed & Upregulate TYMS expression & {$[203]$} \\
& Downregulation of KANK1 that abrogate CXXC5-mediated & apoptosis & {$[204]$} \\
miR-204 & Underexpressed & Directly targets HGMA2 that activates the PI3K/Akt signaling & pathway \\
miR-214 & Underexpressed & Downregulation of HSP27 & {$[205]$} \\
miR-543 & Overexpressed & Upregulation of PTEN that activates the PI3K/AKT signaling & {$[206]$} \\
miR-15b & Underexpressed & pathway & {$[207]$} \\
miR-106a & Overexpressed & Downregulation of TGF $\beta R 2$ that promotes EMT and inhibit & {$[208]$} \\
miR-206 & Underexpressed & apoptosis & {$[209]$} \\
miR-532 & Underexpressed & Enhanced Bcl-2 expression & {$[194]$} \\
miR-494 & Underexpressed & Upregulation of TOP2 $\alpha$ that facilitates DNA-damage repair & {$[195]$} \\
miR-125b & Underexpressed & Induction of Sp1/CD248 expression & {$[210]$} \\
miR-377 & Underexpressed & Induction of BRD4 expression & {$[211]$} \\
miR-139 & Underexpressed & Modulation of NOTCH1, Bcl-2, and AMFR expression & {$[212]$} \\
miR-27b & Underexpressed & Upregulation of ATG10 that promotes autophagy & {$[213]$} \\
\hline
\end{tabular}

Regulation of miRNAs can be influenced by other genes and proteins. For instance, reduced levels of miR-125b have been demonstrated to result in toll-like receptor 2 (TLR2)/ 6 and TLR5 overexpression [214]. Subsequently, miR-125b-5p downregulation induces specificity protein 1 (Sp1)-mediated activation of CD248 that does trigger not only tumor cells metastases but also 5-FU chemoresistance. Up-regulation of lncRNA POU6F2-AS2 is shown to inhibit miR-377 expression, leading towards BRD4 upregulation which in turn promotes tumor cell proliferation, cell cycle progression, and reduced 5-FU cytotoxicity [211]. In a different study, sponging miR-139-5p attributed by LINC00152 overexpression has been linked to diminishing 5-FU-induced apoptosis in colon cancer cells via notch homolog 1, translocation-associated (NOTCH1), Bcl-2, and autocrine motility factor receptor (AMFR) regulations [212]. Recent studies on other microRNAs include miR-27b-3p that acts as a tumor-suppressor. By regulating ATG10, a protein essential for autophagosome formation, it markedly increases the sensitivity of colon cancer cells to 5-FU in vivo [213].

\subsection{Redox Imbalances}

The role reactive oxygen species (ROS) plays in regulating various signaling pathways that may initiate tumorigenesis, differentiation, and apoptosis have been widely docu- 
mented [215]. Elevated levels of ROS due to redox imbalance characterized by increased free radical hydroxyl radical $(\bullet \mathrm{OH})$, hydrogen peroxide $\left(\mathrm{H}_{2} \mathrm{O}_{2}\right)$, hydroperoxyl radical $\left(\mathrm{HO}_{2} \bullet\right)$, and superoxide anion $\left(\mathrm{O}_{2} \bullet^{-}\right)$can induce DNA damage, cell cycle arrests, as well as autophagy via oxidative stress [216,217]. ROS may also influence tumor cell response to chemotherapy. In a recent study, the inhibition of nuclear factor erythroid 2-related factor 2 (Nrf2) as the key transcription factor in the regulation of cellular redox homeostasis has resulted in the re-sensitization of 5-FU in colon cancer cells [218]. Nrf2 inhibition triggered by FoxO3 upregulation caused a significant reduction in TR1 expression that in turn, elevates intracellular ROS. Synergistic interaction between ROS with 5-FU to further trigger apoptotic cell death in resistant cells was further supported in another study by Yan and colleagues (2019) [217]. It was determined that increased intracellular ROS had induced AMP-activated protein kinase (AMPK) signaling pathway activation that promotes autophagy initiation and reverse 5-FU resistance in colon cancer cells.

\section{Mechanism of Resistance by Key 5-Fluorouracil Enzymes}

\subsection{Amplification of Thymidylate Synthase}

Inhibition of thymidylate synthase enzymatic activity has been the hallmark cytotoxic mechanism of 5-FU treatment. Under normal physiological conditions, TYMS is responsible for the irreversible methylation of dUMP to dTMP with the aid from $\mathrm{CH}_{2} \mathrm{THF}$ as the methyl donor [219]. The absence of TYMS thus, hinders the production of nucleolar thymidine as an essential DNA nucleoside, leading towards de novo DNA synthesis impairment within cells. Given that tumor cells are associated with accelerated rates of DNA replication and repair due to increased genomic instability, it is thus more affected than healthy cells [220]. A growing amount of evidence has presented the prognostic value of TYMS, as reduced expression denotes improved patient response and OS to 5-FU-based therapy [221,222]. This corresponds to early studies by which an inverse relationship is observed between TYMS expression and 5-FU chemosensitivity $[223,224]$. Accordingly, increased TYMS amplification has been recognized as a primary determinant in the development of 5-FU resistance (Table 2) [225]. 


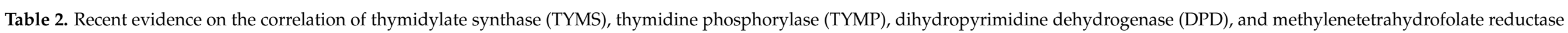
(MTHFR) expression with 5-FU chemosensitivity in colon cancer cell lines and patients.

\section{Enzyme}

Resistance Mechanism

MS overexpression

Thymidylate synthase

via gene amplification through CNV and tandem repeats

Thymidine phosphorylase

TYMP suppression via

DPD upregulation via polymorphism
Dihydropyrimidine dehydrogenase loss-of-function

\section{Recent Evidence}

Outcome

- $\quad$ Resistance in patients with $5^{\prime}$-UTR 2R/3G, 3C/3G, and 3G/3G polymorphisms [226].

- Increase disease relapse in patients with $3^{\prime} \mathrm{UTR}$ ins/LOH polymorphism [227].

- $\quad$ TYMS copy number gains in patients treated with 5-FU [7].

- Increased TYMS expression in 5-FU-resistant colon cancer cell line [228].

- TYMS knockdown enhances 5-FU chemosensitivity in colon cancer cell line [202].

- Meta-analysis: poor patients' prognosis when TYMP is suppressed [229].

- Increase disease recurrence in patients with TYMP underexpression [230].

- Low TYMP expression is associated with reduced patients' relapse-free survival (RFS) [231].

- $\quad$ Low TYMP is associated with poor patient outcome [232].

- Low TYMP is associated with shorter patients RFS and increased risk of disease recurrence [233].

- TYMP upregulation is associated with enhanced 5-FU accumulation and response in colon cancer cell line [234].

- $\quad$ DPD is upregulated in 5-FU-resistant mice [235].

- DPD downregulation demonstrated anti-5-FU resistance in colon cancer cell line [236].

- DPDI-1, ethynyluracil DPDI-2, S-1 DPDI-3, and BOF-A2 DPDI-4 was demonstrated as effective DPD inhibitors that can potentiate 5-FU [237].

- $\quad$ DPD polymorphism profile may serve as an independent risk factor of 5-FU chemosensitivity [226].

- $\quad$ DPD upregulation is observed in 5-FU-resistant mice [238].

- Patients with rs1801131 point mutation are associated with shorter OS and disease-free survival (DFS) [239].

Methylenetetrahydrofolate MTHFR upregulation reductase via polymorphism
- MTHFR $1298 \mathrm{~A} / \mathrm{A}$ and heterozygous MTHFR $677 \mathrm{C} / \mathrm{T}$ genotype is
Restored level of dTMP

Reduced intra-tumoral concentration of active 5-FU metabolite associated with 5-FU resistance in colon cancer cell lines [240]. 
Underlying mechanisms leading towards TYMS amplification have been attributed to the incidence of copy number variation $(\mathrm{CNV})$ and tandem repeat polymorphism within the $5^{\prime}$-untranslated regions $\left(5^{\prime}\right.$-UTR) of TYMS gene. Due to its polymorphic nature, the $5^{\prime}$-UTR region is inclined to contain a double (2R) or triple (3R) 28 base-pair tandem repeats, as well as $\mathrm{G}>\mathrm{C}$ single nucleotide polymorphism (SNP) that may significantly affect TYMS translation. In recent studies, 5-FU chemotherapy efficacy was found markedly reduced by $50 \%$ in patient cohort afflicted with $5^{\prime}-\mathrm{UTR} 2 \mathrm{R} / 3 \mathrm{G}, 3 \mathrm{C} / 3 \mathrm{G}$, and $3 \mathrm{G} / 3 \mathrm{G}$ polymorphisms, when compared to $5^{\prime}$-UTR $2 R / 2 R, 2 R / 3 C$, and $3 C / 3 C$ carriers [226]. While in separate studies, the loss of heterozygosity $(\mathrm{LOH})$ was factored in as well, reporting lower risk of disease recurrence and death for patients with $2 \mathrm{G} / 3 \mathrm{G}, 2 \mathrm{G} / \mathrm{LOH}$, and $3 \mathrm{C} / \mathrm{LOH}$ genotypes [227]. Although no correlation between 3'-UTR polymorphism and 5-FU efficacy was found in the study conducted by Qihong Nie and colleague (2019), it was established by Ntavatzikos and colleagues (2019) that the presence of $3^{\prime}$-UTR ins/LOH is an independent indication for increased risk for disease relapse and death. The phenomenon of TYMS copy number gain upon 5-FU administration in colon cancer patients has also been reported, suggesting the mechanistic approach behind acquired 5-FU resistance is through selective pressure [7]. It is plausible that TYMS overexpression is the negative feedback response of tumor cells to overcome the competitive inhibitory binding of FdUMP as the active substrate of 5-FU.

\subsection{Suppressed Expression of Thymidine Phosphorylase}

Thymidine phosphorylase, or also known as platelet-derived endothelial cell growth factor (PD-ECGF) is another crucial enzyme in the metabolism of 5-FU, involved in the conversion of 5-FU to FdUR prior to its phosphorylation by thymidine kinase (TK) to FdUMP [241]. TYMP overexpression may promote increased intracellular concentration of active 5-FU metabolite, thus enhancing its efficacy. Even so, its direct correlation in 5-FU treatment outcome was previously a subject of debate as certain studies linking elevated expression with worse patient prognosis [242-244]. Recent studies later conclusively determined that TYMP overexpression may only benefit early-stage patients in prolonging time to disease progression, relapse-free survival, and OS [229-233,245]. This is supported by experimental studies in which enhanced 5-FU cytotoxicity is observed in conditions where TYMP is upregulated in colon cancer cells and xenograft mice [234,246]. Accordingly, reduced levels of TYMP may contribute to the development of acquired 5-FU resistance [247]. Poor patient outcomes observed in advanced-stage patients despite elevated levels of TYMP may be attributed to the dual role of TYMP in promoting angiogenesis and metastasis, aside from its role in 5-FU metabolism [222,231]. Such discrepancy may be the result of contrasting treatment regimens between primary and metastatic tumors as the administration of oxaliplatin, irinotecan, and capecitabine alongside 5-FU may provoke TYMP expression [248,249].

Little to no evidence has been presented to attribute TYMP dysregulation with genetic changes of TYMP gene [250]. Genetic variations of TYMP are generally linked with the incidence of mitochondrial neurogastrointestinal encephalomyopathy syndrome (MNGIE) as an autosomal recessive disorder that affects the gastrointestinal and nervous systems [251]. The condition is due to the loss of function of TYMP gene following homozygous mutations c.1283 G > A, and c.1284 T > A, as well as mutations in DNA polymerase subunit gamma (POLG) and ribonucleotide reductase regulatory TP53 inducible subunit M2B (RRM2B) genes that lead to TYMP deficiency [252-254]. Interestingly, increased TYMP expression has been reported in cases of local inflammations such as rheumatoid arthritis and psoriasis, suggesting its plausible causal link with stress conditions such as hypoxia in the tumor microenvironment $[255,256]$. Indeed, TYMP overexpression may promote adaptive responses mediated by the hypoxia-inducible factor (HIF-1) pathway that prevents hypoxia-induced apoptosis that is triggered upon continuous chemotherapy [229,242,257]. Consequently, attenuation of 5-FU chemosensitivity can be observed across varying tumor cells exposed to hypoxic conditions, including colon cancer cells [258-260]. 


\subsection{Overexpression of Dihydropyrimidine Dehydrogenase}

Dihydropyrimidine dehydrogenase serves as the initial rate-limiting enzyme in the catabolism of prodrug 5-FU to inactive DHFU and is responsible for approximately $80 \%$ of 5-FU degradation in the liver after bolus infusion. Consequently, DPD moderates the bioavailability and concentration of plasma 5-FU that inversely correlates with 5-FU treatment response in treated patients. In DPD-deficient patients, increased risk and severity of 5-FU-induced toxicity as a result of active 5-FU metabolites accumulation has been described [261,262]. Accordingly, increased intra-tumoral DPD expression may lead to reduced concentration of 5-FU metabolites and subsequently, in the development of 5-FU resistance $[237,263]$. This has been shown evidently in colon cancer cells where higher levels of DPD activity are observed in the liver of nude mice xenografted with 5-FU-resistant HT-29 cells when compared to nude mice xenografted with 5-FU-sensitive HT-29 cells [235]. Successful in vitro and in vivo reversal of 5-FU resistance in colon cancer cells through DPD inhibition has also been reported in recent studies [236]. Patients displaying heighten adverse events of 5-FU-induced toxicity are often screened for DYPD*2A polymorphisms, particularly in splice site variants $1905+1 \mathrm{G}>\mathrm{A}, \mathrm{c} .1601 \mathrm{G}>\mathrm{A}$ (p.Ser534Asn), c.2194 G > A (p.Val732I1e) [264]. Corrected 5-FU treatment dose is accordingly administered to patients assessed positive for $D Y P D^{*} 2 A$ mutations if the occurring adverse events are deemed intolerable. Despite the toxicity, certain DYPD mutations offer improved tumor response to 5-FU treatment (Table 3) [226].

\subsection{Overexpression of Methylenetetrahydrofolate Reductase}

Inhibition of TYMS is achieved through stable ternary complex formation between TYMS, FdUMP, and $\mathrm{CH}_{2}$ THF. The availability of $\mathrm{CH}_{2} \mathrm{THF}$ for binding, however, is tightlyregulated by the enzyme methylenetetrahydrofolate reductase (MTHFR) that catalyzes the irreversible conversion of active $\mathrm{CH}_{2}$ THF to 5-methylenetetrahydrofolate (5-MTHF) as the essential folate for DNA methylation [267]. Given that TYMS inhibition serves as the principal mechanism behind 5-FU cytotoxicity, MTHFR has been regarded as a factor that may influence the efficacy of 5-FU therapy. It is postulated that MTHFR underexpression may contribute towards enhanced 5-FU efficacy due to a higher concentration of $\mathrm{CH}_{2} \mathrm{THF}$ substrate while its overexpression may manifest in 5-FU resistance. Two common polymorphism variants with the outcome of MTHFR enzymatic deficiency have been identified, namely, the rs1801133 (C677T) and rs1801131 (A1298C) [269]. Positive correlation between MTHFR polymorphisms and colon cancer patient's response to 5-FU treatment is often reported involving variant A1298C with C677T seeing 5-FU benefits only exclusively in refractory cases $[239,270,271]$. Interestingly, in vitro studies have implicated both polymorphisms in the development of 5-FU resistance in colon cancer cells [240]. Nonetheless, several studies had reported no correlation between MTHFR polymorphism and tumor response rate in early-stage patients, supported by in vitro models [272-275]. These variabilities may be contingent with interpatient variability in folate status and treatment history, as better treatment response was reported for MTHFR-mutated patients receiving 5-FU monotherapy when compared to patients with a history of FOLFOX or FOLFIRI treatment [274]. 


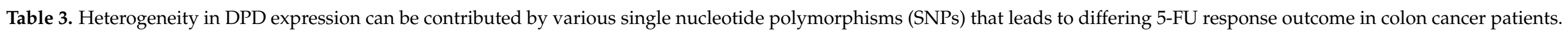

\begin{tabular}{|c|c|c|c|c|c|}
\hline SNP & Gene & Genotype & Outcome & Remark & Ref \\
\hline c. $1905+1$ & $D Y P D^{*} 2 A$ & $\mathrm{G}>\mathrm{A}$ & $\begin{array}{l}\text { - } \quad 50 \% \text { DPD reduction in heterozygous carrier } \\
\text { - } \quad<25 \% \text { DPD reduction in homozygous carrier } \\
\text { - } \quad 40-80 \% \text { 5-FU clearance in heterozygous carrier }\end{array}$ & $\begin{array}{l}\text { - } \quad 0.1 \% \text { in African American population } \\
\text { - } \quad 1 \% \text { in Caucasian population } \\
\text { - } 1.6 \% \text { in European population }\end{array}$ & {$[15,264]$} \\
\hline c. 2846 & D949V & $\mathrm{A}>\mathrm{T}$ & $\begin{array}{l}\text { - } \quad 30 \% \text { DPD reduction in heterozygous carrier } \\
\text { - } \quad 39-59 \% \text { DPD reduction in homozygous carrier } \\
\text { - } \quad 40-80 \% \text { 5-FU clearance in heterozygous carrier }\end{array}$ & $\begin{array}{l}\text { - } \quad 0.1 \% \text { in African American population } \\
\text { - } \quad 1.1 \% \text { in Caucasians } \\
\text { - } \quad 0.7 \% \text { in European population }\end{array}$ & {$[265,266]$} \\
\hline c.1679 & $D Y P D^{*} 13$ & $\mathrm{~T}>\mathrm{G}$ & $\begin{array}{l}\text { - } \quad 68 \% \text { DPD reduction in heterozygous carrier } \\
\text { - } \quad<25 \% \text { DPD reduction in homozygous carrier }\end{array}$ & - $\quad 0.07-0.1 \%$ in Caucasian population & {$[267]$} \\
\hline $\begin{array}{l}\text { c. } 1129-5923 \\
\text { c. } 1236\end{array}$ & HapB3 & $\begin{array}{l}C>G \\
G>A\end{array}$ & $\begin{array}{l}\text { - } \quad 35 \% \text { DPD reduction in heterozygous carrier } \\
\text { - } \quad 41-65 \% \text { DPD reduction in homozygous carrier }\end{array}$ & - $\quad 4.7 \%$ in European population & {$[267,268]$} \\
\hline DPYD*5 & $\mathrm{T} 85 \mathrm{C}$ & $\mathrm{T}>\mathrm{C}$ & - $\quad 39 \%$ reduction in 5-FU efficiency & - $16 \%$ in late-stage patients & [226] \\
\hline $\mathrm{DPYD}^{* 9 \mathrm{~A}}$ & A1627G & $\mathrm{AG}+-\mathrm{GG}$ & - $\quad 100 \%$ reduction in 5-FU efficiency & - $\quad 9 \%$ of late-stage patients & [226] \\
\hline
\end{tabular}




\subsection{Overexpression of Methylenetetrahydrofolate Reductase}

Inhibition of TYMS is achieved through stable ternary complex formation between TYMS, FdUMP, and $\mathrm{CH}_{2}$ THF. The availability of $\mathrm{CH}_{2}$ THF for binding, however, is tightlyregulated by the enzyme methylenetetrahydrofolate reductase (MTHFR) that catalyzes the irreversible conversion of active $\mathrm{CH}_{2} \mathrm{THF}$ to 5-methylenetetrahydrofolate (5-MTHF) as the essential folate for DNA methylation [267]. Given that TYMS inhibition serves as the principal mechanism behind 5-FU cytotoxicity, MTHFR has been regarded as a factor that may influence the efficacy of 5-FU therapy. It is postulated that MTHFR underexpression may contribute towards enhanced 5-FU efficacy due to a higher concentration of $\mathrm{CH}_{2} \mathrm{THF}$ substrate while its overexpression may manifest in 5-FU resistance. Two common polymorphism variants with the outcome of MTHFR enzymatic deficiency have been identified, namely, the rs1801133 (C677T) and rs1801131 (A1298C) [269]. Positive correlation between MTHFR polymorphisms and colon cancer patient's response to 5-FU treatment is often reported involving variant A1298C with C677T seeing 5-FU benefits only exclusively in refractory cases $[239,270,271]$. Interestingly, in vitro studies have implicated both polymorphisms in the development of 5-FU resistance in colon cancer cells [240]. Nonetheless, several studies had reported no correlation between MTHFR polymorphism and tumor response rate in early-stage patients, supported by in vitro models [272-275]. These variabilities may be contingent with interpatient variability in folate status and treatment history, as better treatment response was reported for MTHFR-mutated patients receiving 5-FU monotherapy when compared to patients with a history of FOLFOX or FOLFIRI treatment [274].

\section{Reversal Strategies}

Over the years, various approaches have been undertaken in attempts to promote increased colon cancer tumor cells' sensitivity towards 5-FU treatment that would ultimately improve patient's prognosis. Based on the resistance mechanisms discussed, it can be summarized that reduced levels of TYMS, DPD, MTHFR, as well as increased levels of TYMP would greatly benefit in 5-FU re-sensitization as these enzymes are directly involved in its metabolism and degradation. In the meantime, increased drug influx, apoptosis events, DNA-damage repair, and cell cycle progression, together with reduced drug efflux and autophagy activity would not only aid in reversing 5-FU resistance, but also in the incidence of MDR. Although seemed fairly straightforward, strategies to overcome resistance through actualizing these reverse mechanisms have remained a significant challenge owing to the high complexity and heterogeneity of tumor cells that are not just between individuals, but also in between tumor cells within the same microenvironment attributed to clonal evolution. A plethora of small molecule inhibitors (SMIs), non-coding RNAs, and plant-derived small molecules have nonetheless been investigated in recent years for its potential to overcome 5-FU resistance given the circumstances. Considerable advancements in the field of genomics, proteomics, and metabolomic through high-throughput technologies in recent years have also allowed for resistance profiling in between patients that would aid in personalized medicine to minimize the risk of chemotherapy failure.

\subsection{Small Molecule Inhibitors}

Table 4 summarizes the small inhibitors that can enhance 5-FU chemosensitivity. Most of the compounds described having worked synergistically with 5-FU to potentiate its cytotoxicity effects and overcome its resistance falls under the class of small molecule inhibitors. HDAC inhibitors such as depsipeptide and valproic acid (VPA) for instance, are capable of potentiating the antitumor activity of 5-FU in colon cancer via the induction of caspase-3/7 activation, MHC class II gene expression, cell cycle arrest by cyclin-dependent kinase inhibitor 1A (CDKN1A) upregulation, and extensive TYMS downregulation $[275,276]$. The use of VPA has however, been controversial due to its dual role functions of downregulating and upregulating TYMP and TYMS expression, respectively. Synergistic interactions between VPA and 5-FU were only observed in p53 ${ }^{\mathrm{wt}}$ and p53 ${ }^{\mathrm{mut}}$ colon cancer cells, but not in 
p53 $3^{-}$cells. Considering that TYMP upregulation may only benefit patients in earlier stages of cancer due to its adverse role in promoting angiogenesis in advanced stages and that $\mathrm{p} 53^{-}$ cells are often associated with advanced stages, the use of VPA would appear paradoxical. Further downregulation of TYMS can also be achieved through co-treatment with mitogenactivated protein kinase kinase (MEK) inhibitor cobimetib, FOXM1 inhibitor thiostrepton, and heat shock protein 90 (HSP90) inhibitors such as luminespib and ganetespib [277-281]. Interestingly, U0126 as inhibitors of MEK may also restore 5-FU chemosensitivity through the generation of more $\gamma \mathrm{H} 2 \mathrm{AX}$ foci and diminishing the expression of DNA excision repair 1 (ERCC1), aside from suppressing TYMS expression [282]. Based on the resistance mechanisms discussed, certain SMIs recently studied may also be considered as potential agents to potentiate 5-FU cytotoxicity effects. Patients evaluated with higher expression of $A B C$ transporters such as $\mathrm{ABCC} 1, \mathrm{ABCB} 1$, and $\mathrm{ABCG} 2$ for instance, may benefit significantly from 5-FU therapy when co-administered with uracil analogue U-332 that may abrogate the expression of all three transporters [283]. Alternatively, patients assessed with DPD overexpression commonly associated with incidence $D Y P D^{*} 2 A$ polymorphisms may consider the use of 5-FU together with JTE-013 to effectively inhibit S1PR2 as the upstream regulator of DPD expression [236]. Gimeracil is another reversible inhibitor of DPD, known to be combined alongside oteracil potassium and tegafur as prodrug 5-FU, in a preparation simply termed as S-1 [284]. Stage III colon cancer patients receiving S-1 plus oxaliplatin reported a slight improvement in 3-year DFS when compared to patients receiving only tegafur-uracil plus leucovorin. Other small molecule inhibitors studied to be effective in reversing 5-FU in colon cancer cells may include phospholipase A2 inhibitor quinacrine that enhances c-Jun N-terminal kinase (JNK1)-dependent Nrf2 degradation, and DNA methyltransferase inhibitor decitabine that demethylates TYMP promoter (Table 4) $[285,286]$. For patients with advanced disease, TYMP inhibitor such as tipiracil may not only potentiate the antiproliferative effects of 5-FU but also impede the progression of metastasis [287]. Interestingly, tipiracil has already been actively-used alongside other molecules in the U.S. Food and Drug Administration (FDA)-approved compound TAS-102 for the treatment of metastatic colon cancer.

Table 4. Small molecule inhibitors that have been recently demonstrated to be capable in potentiating 5-FU chemosensitivity in colon cancer cells.

\begin{tabular}{|c|c|c|c|}
\hline Small Molecule Inhibitor & Target & Mechanism & Ref \\
\hline Depsipeptide & \multirow{3}{*}{ HDAC } & $\begin{array}{l}\text { Elevation of MHC class II expression and cellular } \\
\text { apoptosis }\end{array}$ & [275] \\
\hline \multirow{2}{*}{$\begin{array}{l}\text { Valproic acid (VPA) } \\
\text { Suberanilohydroxamic acid } \\
\text { (SAHA) }\end{array}$} & & Modulation of TYMS and TYMP expression & [276] \\
\hline & & Decreased TYMS mRNA and protein expression & [288] \\
\hline Cobimetinib & \multirow{3}{*}{ MEK } & \multirow{3}{*}{$\begin{array}{l}\text { Decreased TYMS expression } \\
\text { Abrogation of TK1 expression } \\
\text { Generation of more } \gamma \mathrm{H} 2 \mathrm{AX} \text { foci, diminishing } \\
\text { ERCC } 1 \text { and TYMS expression }\end{array}$} & [280] \\
\hline Selumetinib & & & [289] \\
\hline U0126 & & & [282] \\
\hline Thiostrepton & FOXM1 & $\begin{array}{l}\text { Suppression of TYMS expression and the regulation } \\
\text { of TK-1 and TYMPS expression }\end{array}$ & [281] \\
\hline $\begin{array}{l}\text { Luminespib } \\
\text { Ganetespib }\end{array}$ & HSP90 & $\begin{array}{l}\text { Downregulation of TYMS } \\
\text { Not stated }\end{array}$ & $\begin{array}{c}{[277,278]} \\
{[279]}\end{array}$ \\
\hline Apatorsen & HSP27 & Accelerated apoptosis & [290] \\
\hline $\begin{array}{l}\text { Ibrutinib } \\
\text { AVL-292 }\end{array}$ & BTK & $\begin{array}{l}\text { Inhibition of TGFB1 protective response and } \\
\text { induction of pro-apoptotic E2F expression }\end{array}$ & [291] \\
\hline Trimethylglycine & STAT6 & $\begin{array}{l}\text { Increased E-cadherin marker and decreased ERCC1 } \\
\text { expression }\end{array}$ & [292] \\
\hline JTE-013 & S1PR2 & Downregulation of DPD expression & [236] \\
\hline Gimeracil & DPD & Downregulation of DPD expression & [293] \\
\hline
\end{tabular}


Table 4. Cont.

\begin{tabular}{|c|c|c|c|}
\hline Small Molecule Inhibitor & Target & Mechanism & Ref \\
\hline Quinacrine & Nrf2 & $\begin{array}{l}\text { Increases the susceptibility of tumor cells to } 5-\mathrm{FU} \\
\text { under hypoxic conditions }\end{array}$ & [285] \\
\hline Tipiracil & TYMP & Downregulations of TYMP & [118] \\
\hline F5446 & SUV39H1 & $\begin{array}{l}\text { Increased Fas expression and FasL-induced } \\
\text { apoptosis }\end{array}$ & [293] \\
\hline $\begin{array}{l}\text { Aminooxyacetic acid } \\
\text { (AOAA) }\end{array}$ & $\begin{array}{l}\text { Hydrogen } \\
\text { sulfide }\end{array}$ & Downregulations of TYMS and EREG expression & [294] \\
\hline SLC-0111 & $\begin{array}{c}\text { Carbonic } \\
\text { anhydrase IX }\end{array}$ & Not stated & [295] \\
\hline AT7519 & CDK & Not stated & [296] \\
\hline Ribavirin & Eif4E & $\begin{array}{l}\text { Increased cell cycle arrest at } \mathrm{G}_{2} / \mathrm{M} \text { phase via } \\
\text { increased cyclin B1, p-histone (Ser10), and Mad2 } \\
\text { expression }\end{array}$ & [297] \\
\hline $\begin{array}{l}\text { Diethylaminobenzaldehyde } \\
\text { (DEAB) }\end{array}$ & ALDH1 & Not stated & [126] \\
\hline
\end{tabular}

\subsection{Plant-Derived Small Molecules}

The high toxicity and lack of specificity of many synthetic resistance-reversing agents have also motivated studies to highlight the plausible potentials of the natural dietary bioactive compound such as flavonoids to combat drug resistance. In fact, nearly half of newly identified compounds and newly discovered drugs were derived from studies on natural products [298]. Sophorae flavescens or shrubby sophora, is a plant with a long history of use in traditional Chinese medicines to elicit antioxidants effects and immunity enhancement. When co-treated with 5-FU in colon cancer cells, compound Sophora injection had also improved 5-FU cytotoxic effects by downregulating the expression of P-gp and ABCG2 that resulted in an increase in drug accumulation within treated cells [26]. Induction of sensitivity may also likely be attributed to the inhibition of EMT and NF- $\mathrm{kB}$ pathways mediated by oxymatrine as one of the many bioactive components contained in Sophora injection [92]. Similar resistance-reversing effects were observed in oxaliplatintreated cells, suggesting the potential of Sophora in reversing MDR. Correspondingly, phytosterol $\beta$-sitosterol, although it has only been shown to reverse oxaliplatin resistance in oxaliplatin-resistant cells, it may also work to reverse 5-FU resistance due to its potential in MDR modulation through the downregulation of BCRP expression [299]. Natural phenol curcumin is the bioactive compound responsible for the bright yellow pigment of turmeric. It was demonstrated that 5-FU therapy, when combined with curcumin, exhibited increased activation of 5-FU-triggered apoptosis in 5-FU-resistant cells through the effective inhibition of the Wnt signaling pathway and EMT activity mediated by curcumin treatment [91]. Downstream effects by these plant-derived small molecules may also be achieved through the regulations of non-coding RNAs. Ethanolic extract of fruit spike Spica Prunellae has shown to enhance 5-FU sensitivity in colon cancer cells by upregulating the expression of miR-494, which in turn, downregulates TOP2 $\alpha$ expression [195]. Meanwhile, fruit-originated lignan schizandrin A may enhance 5-FU chemosensitivity by upregulating miR-195 that inhibits the PI3K/AKT and NF- $\mathrm{kB}$ signaling pathways [300]. Additionally, phenolic compound Kaempferol may work to impede the production of ROS and modulate the expression of JAK/STAT3/MAPK/PI3K/AKT, and NF-KB to reverse 5-FU resistance [28]. Recent studies on other plant-derived small molecules include the 
traditional Chinese medicine herbal formula Huang Qin Ge Gen Tang that modulates the E2F1/TS pathway, green tea extracted polyphenol epigallocatechin gallate that upregulates miR-155 to suppress MDR1 expression, $\beta$-elemene that can induce pro-death autophagy, and xanthonoid $\alpha$-mangostin that have been successful in enhancing 5-FU cytotoxicity in colon cancer cells [59,81,301,302].

\subsection{Non-Coding RNAs Regulators}

In ovarian cancer cells, lncRNA taurine upregulated 1 (TUG1) overexpression has been implicated in the promotion of cellular proliferation and inhibition of apoptosis, suggesting its plausible involvement to also mediate tumorigenesis and chemoresistance in colon cancer cells [303]. Indeed, the knockdown of TUG1 has demonstrated enhanced 5-FU chemosensitivity via the downregulation of TYMS expression in colon cancer cells [228]. Similarly, knockdowns of PVT1, colon cancer-associated transcript 1 (CCAT1), and Xinactive specific transcript (XIST) in 5-FU-resistant colon cancer cells have also resulted in the successful restoration of 5-FU sensitivity [304-306]. Growing evidence has come to suggest lncRNAs exerting their transcriptional effects through functioning as competing endogenous RNAs (ceRNAs) by competitively binding onto miRNA sequence sites [307]. In TUG1-mediated resistance, increased TYMS expression was achieved through the suppression of miR-197-3p via ceRNA sponging, while in CCAT1-mediated resistance, a significant decrease in miR-218, miR-143, and miR-153 expression have been observed. H19 imprinted maternally-expressed transcript (H19) is another lncRNA reported to induce 5-FU resistance. Instead of regulating TYMS, H19 may sponge miR-194-5p to trigger the autophagy process via the SIRT1 enzyme [308]. Effective inhibition of these lncRNAs can be achieved through small interfering RNAs (siRNAs), RNA destabilizing elements (RDEs), antisense oligonucleotides (ASOs), and ribozymes; all of which had been demonstrated to target lncRNAs with high specificity $[309,310]$. In fact, recently, patisiran represents the world's first siRNA-based drug that is FDA-approved for the treatment of hereditary transthyretinmediated amyloidosis via transthyretin (TTR) gene silencing [311]. Additionally, recent advancement in miRNA therapy that saw the successful completion of phase II clinical trial for miR-122 antagonist as an effective antiviral agent against hepatitis $C$ virus (HCV) infection may also be exploited to achieve enhanced 5-FU chemosensitivity [312]. Perhaps, microRNAs previously discussed to be upregulated in 5-FU-resistant cells such as miR-27a, miR-587, miR-31, miR-543, and miR-106a can also be silenced via miRNA repressors for its therapeutic potentials. Meanwhile, microRNA mimics can be applied to overexpress downregulated miRNAs such as miR-361, miR-200c, miR-22, miR-224, and many others. MesomiR-1 and MRG-201 are examples of miRNA mimic currently in phase I of clinical trial for the treatment of malignant pleural mesothelioma and keloid scar tissue formation, respectively [313]. NcRNA delivery strategies in vivo for translational applications have also been looked at in recent years following promising effectiveness of ncRNAs in vitro studies. In their paper, Wang and colleagues (2019) have recognized the reported low bioavailability and transfection efficiency, as well as the occurrence of off-target effects associated with these nucleic acid drugs in vivo. They have underlined several approaches that may benefit to overcome these challenges [314]. They include the use of nanoparticle and oncolytic adenovirus delivery systems, as well as the structured modification to subjected ncRNAs. For instance, engineered-exosomes for targeted co-delivery of miR-21 inhibitor have demonstrated to be effective in reversing 5-FU resistance in vivo [315].

\subsection{Targeted Immunotherapy}

It has been established that TILs are involved in chemotherapy response as elevated levels of chemokine CXCL-13 is determined in sera of 5-FU-resistant patients [145]. Knockdown of CXCL-13 resulted in re-sensitization of tumor cells with a significant increase in the number of B-cell infiltrating into the tumor cells. Furthermore, these resistant cells also highly-express chemokine CCL20 that promotes the recruitment of regulatory $\mathrm{T}$ cells (Tregs) via FOXO1/CEBPB/NF- $\mathrm{BB}$ signaling, suggesting that CCL20 inhibition may pro- 
mote enhanced 5-FU chemosensitivity [151]. Indeed, dendritic cell therapy may appear as a useful strategy in this scenario as it provokes anti-tumor response through the increased number of dendritic cells (DCs) that may present tumor antigens to these lymphocytes. In one study, the use of 5-FU plus oxaliplatin with CD1d-MC38/ $\alpha-G C$ tumor vaccine that promotes DC maturation had synergistically delayed tumor growth rate and increased the survival time of tumor-bearing mice [316]. Tumor cells may also escape immune cells through the secretion of immunosuppressive factors, such as TGF- $\beta$ and IL- 6 , as well as through the recruitment of Tregs [152,158]. Recent studies have also demonstrated the upregulation of PD-L1 as the ligand for immune checkpoint programmed cell death-1 (PD-1) in 5-FU-treated cells promoted the abrogation of T-cell proliferation via the inhibition of PI3K/AKT signaling pathway [317,318]. Surprisingly, the use of PD-1 inhibitor Nivolumab alongside 5-FU, has instead promoted increased tumor cells tolerance against 5-FU [319].

\section{Conclusions}

Resistance to 5-FU, either intrinsic or acquired, can be attributed to various underlying mechanisms that may influence its cellular bioavailability, metabolism, and antitumor effects within tumor cells. These mechanisms are mostly driven by various aberrantlyexpressed genes and proteins as the pro-survival response of tumor cells to tolerate 5FU-induced cytotoxicity. Since tumor responses to 5-FU treatment may vary between individuals due to genetic heterogeneity and clonal evolution of tumor microenvironment, the practice of personalized medicine is perhaps the best way forward in the effort to overcome 5-FU resistance and improve 5-FU treatment response in colon cancer patients. The dysregulated tumor response to 5-FU treatment can be profiled in each patient and can be independently restored to regular function to overcome 5-FU resistance.

Author Contributions: Conceptualization, S.A. and H.F.S.; writing—original draft preparation, S.A.; writing, review and editing, H.F.S., M.F.J., N.M., and M.A. All authors have read and agreed to the published version of the manuscript.

Funding: This research received no external funding.

Institutional Review Board Statement: Not applicable.

Informed Consent Statement: Not applicable.

Data Availability Statement: Not applicable.

Acknowledgments: We thank all cited authors for their groundwork in producing high-quality articles for this review.

Conflicts of Interest: The authors declare no conflict of interest.

\section{References}

1. Keum, N.; Giovannucci, E. Global burden of colorectal cancer: Emerging trends, risk factors and prevention strategies. Nat. Rev. Gastroenterol. Hepatol. 2019, 16, 713-732. [CrossRef] [PubMed]

2. Wong, M.C.; Ding, H.; Wang, J.; Chan, P.S.; Huang, J. Prevalence and risk factors of colorectal cancer in Asia. Intest. Res. 2019, 17, 317-329. [CrossRef] [PubMed]

3. Idrees, M.; Tejani, M. Current Treatment Strategies for Elderly Patients with Metastatic Colon Cancer. Cureus 2019,11 , e4713. [CrossRef] [PubMed]

4. Heidelberger, C.; Chaudhuri, N.K.; Danneberg, P.; Mooren, D.; Griesbach, L.; Duschinsky, R.; Schnitzer, R.J.; Pleven, E.; Scheiner, J. Fluorinated pyrimidines, a new class of tumour-inhibitory compounds. Nature 1957, 179, 663-666. [CrossRef] [PubMed]

5. Vodenkova, S.; Buchler, T.; Cervena, K.; Veskrnova, V.; Vodicka, P.; Vymetalkova, V. 5-fluorouracil and other fluoropyrimidines in colorectal cancer: Past, present and future. Pharmacol. Ther. 2020, 206, 107447. [CrossRef]

6. Xie, Y.-H.; Chen, Y.-X.; Fang, J.-Y. Comprehensive review of targeted therapy for colorectal cancer. Signal Transduct. Target. Ther. 2020, 5, 22. [CrossRef]

7. Christensen, S.; Van der Roest, B.; Besselink, N.; Janssen, R.; Boymans, S.; Martens, J.W.M.; Yaspo, M.-L.; Priestley, P.; Kuijk, E.; Cuppen, E.; et al. 5-Fluorouracil treatment induces characteristic T>G mutations in human cancer. Nat. Commun. 2019, 10, 4571. [CrossRef]

8. Gu, J.; Li, Z.; Zhou, J.; Sun, Z.; Bai, C. Response prediction to oxaliplatin plus 5-fluorouracil chemotherapy in patients with colorectal cancer using a four-protein immunohistochemical model. Oncol. Lett. 2019, 18, 2091-2101. [CrossRef] 
9. Yao, W.; Zhu, S.; Li, P.; Zhang, S. Large tumor suppressor kinase 2 overexpression attenuates 5-FU-resistance in colorectal cancer via activating the JNK-MIEF1-mitochondrial division pathway. Cancer Cell Int. 2019, 19, 97. [CrossRef]

10. Salem, M.E.; Yin, J.; Goldberg, R.M.; Pederson, L.D.; Wolmark, N.; Alberts, S.R.; Taieb, J.; Marshall, J.L.; Lonardi, S.; Yoshino, T.; et al. Evaluation of the change of outcomes over a 10-year period in patients with stage III colon cancer: Pooled analysis of 6501 patients treated with fluorouracil, leucovorin, and oxaliplatin in the ACCENT database. Ann. Oncol. 2020, 31, 480-486. [CrossRef]

11. Ishikawa, K.; Kawano, Y.; Arihara, Y.; Kubo, T.; Takada, K.; Murase, K.; Miyanishi, K.; Kobune, M.; Kato, J. BH3 profiling discriminates the anti-apoptotic status of 5-fluorouracil-resistant colon cancer cells. Oncol. Rep. 2019, 42, 2416-2425. [CrossRef] [PubMed]

12. Rutman, R.J.; Cantarow, A.; Paschkis, K.E. Studies in 2-Acetylaminofluorene Carcinogenesis: III. The Utilization of Uracil-2-C14 by Preneoplastic Rat Liver and Rat Hepatoma. Cancer Res. 1954, 14, 119-123. [PubMed]

13. Jubeen, F.; Liaqat, A.; Sultan, M.; Zafar Iqbal, S.; Sajid, I.; Sher, F. Green synthesis and biological evaluation of novel 5-fluorouracil derivatives as potent anticancer agents. Saudi Pharm. J. 2019, 27, 1164-1173. [CrossRef] [PubMed]

14. Merloni, F.; Ranallo, N.; Scortichini, L.; Giampieri, R.; Berardi, R. Tailored therapy in patients treated with fluoropyrimidines: Focus on the role of dihydropyrimidine dehydrogenase. Cancer Drug Resist. 2019. [CrossRef]

15. Wigle, T.J.; Tsvetkova, E.V.; Welch, S.A.; Kim, R.B. DPYD and Fluorouracil-Based Chemotherapy: Mini Review and Case Report. Pharmaceutics 2019, 11, 199. [CrossRef]

16. Lin, S.; Yue, J.; Guan, X.; Yuan, P.; Wang, J.; Luo, Y.; Fan, Y.; Cai, R.; Li, Q.; Chen, S.; et al. Polymorphisms of MTHFR and TYMS predict capecitabine-induced hand-foot syndrome in patients with metastatic breast cancer. Cancer Commun. 2019, 39, 57. [CrossRef]

17. Yao, C.W.; Kang, K.A.; Piao, M.J.; Ryu, Y.S.; Fernando, P.M.D.J.; Oh, M.C.; Park, J.E.; Shilnikova, K.; Na, S.-Y.; Jeong, S.U.; et al. Reduced Autophagy in 5-Fluorouracil Resistant Colon Cancer Cells. Biomol. Ther. 2017, 25, 315-320. [CrossRef]

18. Ratti, M.; Hahne, J.C.; Toppo, L.; Castelli, E.; Petrelli, F.; Passalacqua, R.; Barni, S.; Tomasello, G.; Ghidini, M. Major innovations and clinical applications of disodium-levofolinate: A review of available preclinical and clinical data. Ther. Adv. Med. Oncol. 2019, 11, 1758835919853954. [CrossRef]

19. Robey, R.W.; Pluchino, K.M.; Hall, M.D.; Fojo, A.T.; Bates, S.E.; Gottesman, M.M. Revisiting the role of ABC transporters in multidrug-resistant cancer. Nat. Rev. Cancer 2018, 18, 452-464. [CrossRef]

20. Han, S.-H.; Kim, J.W.; Kim, M.; Kim, J.H.; Lee, K.-W.; Kim, B.-H.; Oh, H.-K.; Kim, D.-W.; Kang, S.-B.; Kim, H.; et al. Prognostic implication of $\mathrm{ABC}$ transporters and cancer stem cell markers in patients with stage III colon cancer receiving adjuvant FOLFOX-4 chemotherapy. Oncol. Lett. 2019, 17, 5572-5580. [CrossRef]

21. Zhang, Y.; Zhang, Y.; Wang, J.; Yang, J.; Yang, G. Abnormal expression of ABCD3 is an independent prognostic factor for colorectal cancer. Oncol. Lett. 2020, 19, 3567-3577. [CrossRef] [PubMed]

22. Rehman, Z.; Fahim, A.; Bhatti, A.; Sadia, H.; John, P. Co-expression of HIF-1alpha, MDR1 and LAPTM4B in peripheral blood of solid tumors. PeerJ 2019, 7, e6309. [CrossRef] [PubMed]

23. Dvorak, P.; Hlavac, V.; Mohelnikova-Duchonova, B.; Liska, V.; Pesta, M.; Soucek, P. Downregulation of ABC Transporters in Non-neoplastic Tissues Confers Better Prognosis for Pancreatic and Colorectal Cancer Patients. J. Cancer 2017, 8, $1959-1971$. [CrossRef] [PubMed]

24. Wang, H.; Li, J.-M.; Wei, W.; Yang, R.; Chen, D.; Ma, X.-D.; Jiang, G.-M.; Wang, B.-L. Regulation of ATP-binding cassette subfamily B member 1 by Snail contributes to chemoresistance in colorectal cancer. Cancer Sci. 2020, 111, 84-97. [CrossRef]

25. Gao, Q.; Li, X.-X.; Xu, Y.-M.; Zhang, J.-Z.; Rong, S.; Qin, Y.-Q.; Fang, J. IRE1 $\alpha$-targeting downregulates ABC transporters and overcomes drug resistance of colon cancer cells. Cancer Lett. 2020, 476, 67-74. [CrossRef]

26. Yin, W.; Zhong, G.; Fan, H.; Xia, H. The Effect of Compound Sophora on Fluorouracil and Oxaliplatin Resistance in Colorectal Cancer Cells. Evid. Based Complement. Altern. Med. 2019, 2019, 7564232. [CrossRef]

27. Riahi-Chebbi, I.; Souid, S.; Othman, H.; Haoues, M.; Karoui, H.; Morel, A.; Srairi-Abid, N.; Essafi, M.; Essafi-Benkhadir, K. The Phenolic compound Kaempferol overcomes 5-fluorouracil resistance in human resistant LS174 colon cancer cells. Sci. Rep. 2019, 9, 195. [CrossRef]

28. Chen, N.; Kong, Y.; Wu, Y.; Gao, Q.; Fu, J.; Sun, X.; Geng, Q. CAC1 knockdown reverses drug resistance through the downregulation of P-gp and MRP-1 expression in colorectal cancer. PLoS ONE 2019, 14, e0222035. [CrossRef]

29. Zhang, S.; Chatterjee, T.; Godoy, C.; Wu, L.; Liu, Q.J.; Carmon, K.S. GPR56 Drives Colorectal Tumor Growth and Promotes Drug Resistance through Upregulation of MDR1 Expression via a RhoA-Mediated Mechanism. Mol. Cancer Res. 2019, 17, $2196-2207$. [CrossRef]

30. Sun, L.; Ke, J.; He, Z.; Chen, Z.; Huang, Q.; Ai, W.; Wang, G.; Wei, Y.; Zou, X.; Zhang, S.; et al. HES1 Promotes Colorectal Cancer Cell Resistance To 5-Fu by Inducing Of EMT and ABC Transporter Proteins. J. Cancer 2017, 8, 2802-2808. [CrossRef]

31. Hu, H.; Wang, M.; Guan, X.; Yuan, Z.; Liu, Z.; Zou, C.; Wang, G.; Gao, X.; Wang, X. Loss of ABCB4 attenuates the caspasedependent apoptosis regulating resistance to 5-Fu in colorectal cancer. Biosci. Rep. 2018, 38. [CrossRef] [PubMed]

32. Pasello, M.; Giudice, A.M.; Scotlandi, K. The ABC subfamily A transporters: Multifaceted players with incipient potentialities in cancer. Semin. Cancer Biol. 2020, 60, 57-71. [CrossRef] [PubMed]

33. Zhang, Z.; Feng, L.; Liu, P.; Duan, W. ANRIL promotes chemoresistance via disturbing expression of ABCC1 by regulating the expression of Let-7a in colorectal cancer. Biosci. Rep. 2018, 38, BSR20180620. [CrossRef] [PubMed] 
34. Schaller, L.; Lauschke, V.M. The genetic landscape of the human solute carrier (SLC) transporter superfamily. Hum. Genet. 2019, 138, 1359-1377. [CrossRef] [PubMed]

35. Young, J. The SLC28 (CNT) and SLC29 (ENT) nucleoside transporter families: A 30-year collaborative odyssey. Biochem. Soc. Trans. 2016, 44, 869-876. [CrossRef]

36. Mohelnikova-Duchonova, B.; Melichar, B.; Soucek, P. FOLFOX/FOLFIRI pharmacogenetics: The call for a personalized approach in colorectal cancer therapy. World J. Gastroenterol. 2014, 20, 10316-10330. [CrossRef]

37. Phua, L.C.; Mal, M.; Koh, P.K.; Cheah, P.Y.; Chan, E.C.Y.; Ho, H.K. Investigating the role of nucleoside transporters in the resistance of colorectal cancer to 5-fluorouracil therapy. Cancer Chemother. Pharmacol. 2013, 71, 817-823. [CrossRef]

38. Wang, W.-B.; Yang, Y.; Zhao, Y.-P.; Zhang, T.-P.; Liao, Q.; Shu, H. Recent studies of 5-fluorouracil resistance in pancreatic cancer. World J. Gastroenterol. 2014, 20, 15682-15690. [CrossRef]

39. Ren, A.; Sun, S.; Li, S.; Chen, T.; Shu, Y.; Du, M.; Zhu, L. Genetic variants in SLC22A3 contribute to the susceptibility to colorectal cancer. Int. J. Cancer 2019, 145, 154-163. [CrossRef]

40. Kikuchi, D.; Saito, M.; Saito, K.; Watanabe, Y.; Matsumoto, Y.; Kanke, Y.; Onozawa, H.; Hayase, S.; Sakamoto, W.; Ishigame, T.; et al. Upregulated solute carrier family 37 member 1 in colorectal cancer is associated with poor patient outcome and metastasis. Oncol. Lett. 2018, 15, 2065-2072. [CrossRef]

41. Sheng, N.; Yan, L.; You, W.; Tan, G.; Gong, J.; Chen, H.; Yang, Y.; Hu, L.; Wang, Z. Knockdown of SLC39A7 inhibits cell growth and induces apoptosis in human colorectal cancer cells. Acta Biochim. Biophys. Sin. 2017, 49, 926-934. [CrossRef] [PubMed]

42. Or, C.-H.R.; Huang, C.-W.; Chang, C.-C.; Lai, Y.-C.; Chen, Y.-J.; Chang, C.-C. Obatoclax, a Pan-BCL-2 Inhibitor, Downregulates Survivin to Induce Apoptosis in Human Colorectal Carcinoma Cells Via Suppressing WNT/ $\beta$-catenin Signaling. Int. J. Mol. Sci. 2020, 21, 1773. [CrossRef] [PubMed]

43. Knoll, G.; Riffelsberger, P.; Raats, D.; Kranenburg, O.; Ehrenschwender, M. NOXA-dependent contextual synthetic lethality of BCL-XL inhibition and "osmotic reprogramming" in colorectal cancer. Cell Death Dis. 2020, 11, 257. [CrossRef] [PubMed]

44. Zhao, C.; Ghosh, B.; Chakraborty, T.; Roy, S. Bavachinin mitigates DMH induced colon cancer in rats by altering p53/Bcl2/BAX signaling associated with apoptosis. Biotech. Histochem. 2020. [CrossRef]

45. Al-Obeed, O.; El-Obeid, A.S.; Matou-Nasri, S.; Vaali-Mohammed, M.-A.; AlHaidan, Y.; Elwatidy, M.; Al Dosary, H.; Alehaideb, Z.; Alkhayal, K.; Haseeb, A.; et al. Herbal melanin inhibits colorectal cancer cell proliferation by altering redox balance, inducing apoptosis, and modulating MAPK signaling. Cancer Cell Int. 2020, 20, 126. [CrossRef]

46. Scherr, A.-L.; Gdynia, G.; Salou, M.; Radhakrishnan, P.; Duglova, K.; Heller, A.; Keim, S.; Kautz, N.; Jassowicz, A.; Elssner, C.; et al. Bcl-xL is an oncogenic driver in colorectal cancer. Cell Death Dis. 2016, 7, e2342. [CrossRef]

47. Fu, J.; Xu, Y.; Yang, Y.; Liu, Y.; Ma, L.; Zhang, Y. Aspirin suppresses chemoresistance and enhances antitumor activity of 5-Fu in 5-Fu-resistant colorectal cancer by abolishing 5-Fu-induced NF-kB activation. Sci. Rep. 2019, 9, 16937. [CrossRef]

48. Yang, Y.; Ma, L.; Xu, Y.; Liu, Y.; Li, W.; Cai, J.; Zhang, Y. Enalapril overcomes chemoresistance and potentiates antitumor efficacy of 5-FU in colorectal cancer by suppressing proliferation, angiogenesis, and NF-кB/STAT3-regulated proteins. Cell Death Dis. 2020, 11, 477. [CrossRef]

49. Koosha, S.; Mohamed, Z.; Sinniah, A.; Alshawsh, M.A. Investigation into the Molecular Mechanisms underlying the Antiproliferative and Anti-tumorigenesis activities of Diosmetin against HCT-116 Human Colorectal Cancer. Sci. Rep. 2019 , 9, 5148. [CrossRef]

50. Dai, X.; Zhou, B.; Xie, Y.; Lou, J.; Li, K. Bufalin and 5-fluorouracil synergistically induce apoptosis in colorectal cancer cells. Oncol. Lett. 2018, 15, 8019-8026. [CrossRef]

51. Ramesh, P.; Medema, J.P. BCL-2 family deregulation in colorectal cancer: Potential for BH3 mimetics in therapy. Apoptosis 2020, 25, 305-320. [CrossRef] [PubMed]

52. Wang, Y.; Liu, X.; Liu, J.; Zhang, T. Knockdown of REG I $\alpha$ Enhances the Sensitivity to 5-Fluorouracil of Colorectal Cancer Cells via Cyclin D1/CDK4 Pathway and BAX/BCL-2 Pathways. Cancer Biother. Radiopharm. 2019, 34, 362-370. [CrossRef] [PubMed]

53. Lan, W.; Zhao, J.; Shang, H.; Peng, J.; Chen, W.; Lin, J. Anlotinib overcomes multiple drug resistant of the colorectal cancer cells via inactivating PI3K/AKT pathway. bioRxiv 2019, 821801. [CrossRef]

54. Srivastava, R.; Cao, Z.; Nedeva, C.; Naim, S.; Bachmann, D.; Rabachini, T.; Gangoda, L.; Shahi, S.; Glab, J.; Menassa, J.; et al. BCL-2 family protein BOK is a positive regulator of uridine metabolism in mammals. Proc. Natl. Acad. Sci. USA 2019, 116, 15469-15474. [CrossRef]

55. Benhalilou, N.; Alsamri, H.; Alneyadi, A.; Athamneh, K.; Alrashedi, A.; Altamimi, N.; Al Dhaheri, Y.; Eid, A.H.; Iratni, R. Origanum majorana Ethanolic Extract Promotes Colorectal Cancer Cell Death by Triggering Abortive Autophagy and Activation of the Extrinsic Apoptotic Pathway. Front. Oncol. 2019, 9, 795. [CrossRef]

56. Tigu, A.B.; Toma, V.-A.; Mot, A.C.; Jurj, A.; Moldovan, C.S.; Fischer-Fodor, E.; Berindan-Neagoe, I.; Pârvu, M. The Synergistic Antitumor Effect of 5-Fluorouracil Combined with Allicin against Lung and Colorectal Carcinoma Cells. Molecules 2020, $25,1947$. [CrossRef]

57. Koosha, S.; Mohamed, Z.; Sinniah, A.; Ibrahim, Z.A.; Seyedan, A.; Alshawsh, M.A. Antiproliferative and apoptotic activities of 8-prenylnaringenin against human colon cancer cells. Life Sci. 2019, 232, 116633. [CrossRef]

58. Rani, I.; Sharma, B.; Kumar, S.; Kaur, S.; Agnihotri, N. Apoptosis mediated chemosensitization of tumor cells to 5-fluorouracil on supplementation of fish oil in experimental colon carcinoma. Tumor Biol. 2017, 39, 1010428317695019. [CrossRef] 
59. Lee, J.; Kang, J.-S.; Choi, B.-Y.; Keum, Y.-S. Sensitization of 5-Fluorouracil-Resistant SNUC5 Colon Cancer Cells to Apoptosis by $\alpha$-Mangostin. Biomol. Ther. 2016, 24, 604-609. [CrossRef]

60. Lee, J.H.; Lee, S.-W. Enhancement of chemosensitivity in 5-fluorouracil-resistant colon cancer cells with carcinoembryonic antigen-specific RNA aptamer. Mol. Biol. Rep. 2019, 46, 3835-3842. [CrossRef]

61. Cervantes-Villagrana, R.D.; Albores-García, D.; Cervantes-Villagrana, A.R.; García-Acevez, S.J. Tumor-induced neurogenesis and immune evasion as targets of innovative anti-cancer therapies. Signal Transduct. Target. Ther. 2020, 5, 99. [CrossRef]

62. Xiao, W.; Ibrahim, M.L.; Redd, P.S.; Klement, J.D.; Lu, C.; Yang, D.; Savage, N.M.; Liu, K. Loss of Fas Expression and Function Is Coupled with Colon Cancer Resistance to Immune Checkpoint Inhibitor Immunotherapy. Mol. Cancer Res. 2019, 17, 420-430. [CrossRef] [PubMed]

63. Bower, J.J.; Vance, L.D.; Psioda, M.; Smith-Roe, S.L.; Simpson, D.A.; Ibrahim, J.G.; Hoadley, K.A.; Perou, C.M.; Kaufmann, W.K. Patterns of cell cycle checkpoint deregulation associated with intrinsic molecular subtypes of human breast cancer cells. NPJ Breast Cancer 2017, 3, 9. [CrossRef] [PubMed]

64. Chen, S.-J.; Chung, Y.-C.; Chang, H.-L.; Chang, H.-P.; Chou, J.-L.; Lin, C.-C.; Chen, C.-H.; Hsu, C.-P. Synergistic Effect of Combined Treatment with Longan Flower Extract and 5-Fluorouracil on Colorectal Cancer Cells. Nutr. Cancer 2020, 72, 209-217. [CrossRef] [PubMed]

65. Francipane, M.G.; Bulanin, D.; Lagasse, E. Establishment and Characterization of 5-Fluorouracil-Resistant Human Colorectal Cancer Stem-Like Cells: Tumor Dynamics under Selection Pressure. Int. J. Mol. Sci. 2019, 20, 1817. [CrossRef]

66. Liu, T.; Wang, X.; Hu, W.; Fang, Z.; Jin, Y.; Fang, X.; Miao, Q.R. Epigenetically Down-Regulated Acetyltransferase PCAF Increases the Resistance of Colorectal Cancer to 5-Fluorouracil. Neoplasia 2019, 21, 557-570. [CrossRef]

67. Nakagawa, Y.; Kajihara, A.; Takahashi, A.; Kondo, N.; Mori, E.; Kirita, T.; Ohnishi, T. The BRCA2 gene is a potential molecular target during 5-fluorouracil therapy in human oral cancer cells. Oncol. Rep. 2014, 31, 2001-2006. [CrossRef]

68. Liu, Z.; Yu, M.; Fei, B.; Sun, J.; Wang, D. Identification Of Natural Compound Derivative For Inhibition Of XLF And Overcoming Chemoresistance In Colorectal Cancer Cells. Drug Des. Dev. Ther. 2019, 13, 3823-3834. [CrossRef]

69. Srinivas, U.S.; Dyczkowski, J.; Beißbarth, T.; Gaedcke, J.; Mansour, W.Y.; Borgmann, K.; Dobbelstein, M. 5-Fluorouracil sensitizes colorectal tumor cells towards double stranded DNA breaks by interfering with homologous recombination repair. Oncotarget 2015, 6, 12574-12586. [CrossRef]

70. Liu, Z.; Yu, M.; Fei, B.; Sun, J.; Wang, D. Nonhomologous end joining key factor XLF enhances both 5-florouracil and oxaliplatin resistance in colorectal cancer. Onco Targets Ther. 2019, 12, 2095-2104. [CrossRef]

71. Chen, X.; Li, W.-F.; Wu, X.; Zhang, H.-C.; Chen, L.; Zhang, P.-Y.; Liu, L.-Y.; Ma, D.; Chen, T.; Zhou, L.; et al. Dicer regulates non-homologous end joining and is associated with chemosensitivity in colon cancer patients. Carcinogenesis 2017, 38, 873-882. [CrossRef] [PubMed]

72. Mei, L.; Zhang, J.; He, K.; Zhang, J. Ataxia telangiectasia and Rad3-related inhibitors and cancer therapy: Where we stand. J. Hematol. Oncol. 2019, 12, 43. [CrossRef] [PubMed]

73. Akasaka, T.; Tsujii, M.; Kondo, J.; Hayashi, Y.; Ying, J.; Lu, Y.; Kato, M.; Yamada, T.; Yamamoto, S.; Inoue, T.; et al. 5FU resistance abrogates the amplified cytotoxic effects induced by inhibiting checkpoint kinase 1 in p53mutated colon cancer cells. Int. J. Oncol. 2015, 46, 63-70. [CrossRef] [PubMed]

74. Narayan, S.; Jaiswal, A.S.; Sharma, R.; Nawab, A.; Duckworth, L.V.; Law, B.K.; Zajac-Kaye, M.; George, T.J.; Sharma, J.; Sharma, A.K.; et al. NSC30049 inhibits Chk1 pathway in 5-FU-resistant CRC bulk and stem cell populations. Oncotarget 2017, 8, 57246-57264. [CrossRef]

75. Yao, J.; Huang, A.; Zheng, X.; Liu, T.; Lin, Z.; Zhang, S.; Yang, Q.; Zhang, T.; Ma, H. 53 BP1 loss induces chemoresistance of colorectal cancer cells to 5-fluorouracil by inhibiting the ATM-CHK2-P53 pathway. J. Cancer Res. Clin. Oncol. 2017, 143, 419-431. [CrossRef]

76. Maiuthed, A.; Ninsontia, C.; Erlenbach-Wuensch, K.; Ndreshkjana, B.; Muenzner, J.K.; Caliskan, A.; Husayn, A.P.; Chaotham, C.; Hartmann, A.; Vial Roehe, A.; et al. Cytoplasmic p21 Mediates 5-Fluorouracil Resistance by Inhibiting Pro-Apoptotic Chk2. Cancers 2018, 10, 373. [CrossRef]

77. Yun, C.W.; Lee, S.H. The Roles of Autophagy in Cancer. Int. J. Mol. Sci. 2018, 19, 3466. [CrossRef]

78. Gu, X.-Y.; Jiang, Y.; Li, M.-Q.; Han, P.; Liu, Y.-L.; Cui, B.-B. Over-expression of EGFR regulated by RARA contributes to 5-FU resistance in colon cancer. Aging 2020, 12, 156-177. [CrossRef]

79. Zhang, P.; Lai, Z.-L.; Chen, H.-F.; Zhang, M.; Wang, A.; Jia, T.; Sun, W.-Q.; Zhu, X.-M.; Chen, X.-F.; Zhao, Z.; et al. Curcumin synergizes with 5-fluorouracil by impairing AMPK/ULK1-dependent autophagy, AKT activity and enhancing apoptosis in colon cancer cells with tumor growth inhibition in xenograft mice. J. Exp. Clin. Cancer Res. 2017, 36, 190. [CrossRef]

80. Yang, J.-W.; Zhang, Q.-H.; Liu, T. Autophagy facilitates anticancer effect of 5-fluorouracil in HCT-116 cells. J. Cancer Res. Ther. 2018, 14, S1141-S1147. [CrossRef]

81. Zhang, R.; Pan, T.; Xiang, Y.; Zhang, M.; Feng, J.; Liu, S.; Duan, T.; Chen, P.; Zhai, B.; Chen, X.; et al. $\beta$-Elemene Reverses the Resistance of p53-Deficient Colorectal Cancer Cells to 5-Fluorouracil by Inducing Pro-death Autophagy and Cyclin D3-Dependent Cycle Arrest. Front. Bioeng. Biotechnol. 2020, 8, 378. [CrossRef] [PubMed]

82. Alnuqaydan, A.M.; Rah, B.; Almutary, A.G.; Chauhan, S.S. Synergistic antitumor effect of 5-fluorouracil and withaferin-A induces endoplasmic reticulum stress-mediated autophagy and apoptosis in colorectal cancer cells. Am. J. Cancer Res. 2020, 10, 799-815. [PubMed] 
83. Liu, S.; Lin, H.; Wang, D.; Li, Q.; Luo, H.; Li, G.; Chen, X.; Li, Y.; Chen, P.; Zhai, B.; et al. PCDH17 increases the sensitivity of colorectal cancer to 5-fluorouracil treatment by inducing apoptosis and autophagic cell death. Signal Transduct. Target. Ther. 2019, 4, 53. [CrossRef] [PubMed]

84. Woźniak, M.; Makuch, S.; Winograd, K.; Wiśniewski, J.; Ziółkowski, P.; Agrawal, S. 6-Shogaol enhances the anticancer effect of 5-fluorouracil, oxaliplatin, and irinotecan via increase of apoptosis and autophagy in colon cancer cells in hypoxic/aglycemic conditions. BMC Complement. Med. Ther. 2020, 20, 141. [CrossRef]

85. Li, X.; Zhou, Y.; Li, Y.; Yang, L.; Ma, Y.; Peng, X.; Yang, S.; Liu, J.; Li, H. Autophagy: A novel mechanism of chemoresistance in cancers. Biomed. Pharmacother. 2019, 119, 109415. [CrossRef]

86. Vu, T.; Datta, P.K. Regulation of EMT in Colorectal Cancer: A Culprit in Metastasis. Cancers 2017, 9, 171. [CrossRef] [PubMed]

87. Huang, K.; Gao, N.; Bian, D.; Zhai, Q.; Yang, P.; Li, M.; Wang, X. Correlation between FAK and EGF-Induced EMT in Colorectal Cancer Cells. J. Oncol. 2020, 2020, 5428920. [CrossRef] [PubMed]

88. Li, Q.; Lai, Q.; He, C.; Fang, Y.; Yan, Q.; Zhang, Y.; Wang, X.; Gu, C.; Wang, Y.; Ye, L.; et al. RUNX1 promotes tumour metastasis by activating the Wnt/ $\beta$-catenin signalling pathway and EMT in colorectal cancer. J. Exp. Clin. Cancer Res. 2019, 38, 334. [CrossRef]

89. Ji, M.; Li, W.; He, G.; Zhu, D.; Lv, S.; Tang, W.; Jian, M.; Zheng, P.; Yang, L.; Qi, Z.; et al. Zinc- $\alpha 2$-glycoprotein 1 promotes EMT in colorectal cancer by filamin A mediated focal adhesion pathway. J. Cancer 2019, 10, 5557-5566. [CrossRef]

90. Wang, K.; Song, K.; Ma, Z.; Yao, Y.; Liu, C.; Yang, J.; Xiao, H.; Zhang, J.; Zhang, Y.; Zhao, W. Identification of EMT-related high-risk stage II colorectal cancer and characterisation of metastasis-related genes. Br. J. Cancer 2020. [CrossRef]

91. Lu, Y.; Zhang, R.; Zhang, X.; Zhang, B.; Yao, Q. Curcumin may reverse 5-fluorouracil resistance on colonic cancer cells by regulating TET1-NKD-Wnt signal pathway to inhibit the EMT progress. Biomed. Pharmacother. 2020, 129, 110381. [CrossRef]

92. Liang, L.; Wu, J.; Luo, J.; Wang, L.; Chen, Z.X.; Han, C.L.; Gan, T.Q.; Huang, J.A.; Cai, Z.W. Oxymatrine reverses 5-fluorouracil resistance by inhibition of colon cancer cell epithelial-mesenchymal transition and NF-кB signaling in vitro. Oncol. Lett. 2020, 19, 519-526. [CrossRef] [PubMed]

93. Li, N.; Babaei-Jadidi, R.; Lorenzi, F.; Spencer-Dene, B.; Clarke, P.; Domingo, E.; Tulchinsky, E.; Vries, R.G.J.; Kerr, D.; Pan, Y.; et al. An FBXW7-ZEB2 axis links EMT and tumour microenvironment to promote colorectal cancer stem cells and chemoresistance. Oncogenesis 2019, 8, 13. [CrossRef] [PubMed]

94. Gasiulè, S.; Dreize, N.; Kaupinis, A.; Ražanskas, R.; Čiupas, L.; Stankevičius, V.; Kapustina, Ž.; Laurinavičius, A.; Valius, M.; Vilkaitis, G. Molecular Insights into miRNA-Driven Resistance to 5-Fluorouracil and Oxaliplatin Chemotherapy: miR-23b Modulates the Epithelial-Mesenchymal Transition of Colorectal Cancer Cells. J. Clin. Med. 2019, 8, 2115. [CrossRef] [PubMed]

95. Galle, E.; Thienpont, B.; Cappuyns, S.; Venken, T.; Busschaert, P.; Van Haele, M.; Van Cutsem, E.; Roskams, T.; van Pelt, J.; Verslype, C.; et al. DNA methylation-driven EMT is a common mechanism of resistance to various therapeutic agents in cancer. Clin. Epigenet. 2020, 12, 27. [CrossRef]

96. Li, Y.; Huang, S.; Li, Y.; Zhang, W.; He, K.; Zhao, M.; Lin, H.; Li, D.; Zhang, H.; Zheng, Z.; et al. Decreased expression of LncRNA SLC25A25-AS1 promotes proliferation, chemoresistance, and EMT in colorectal cancer cells. Tumor Biol. 2016, 1-11. [CrossRef]

97. Chen, D.-L.; Xu, R.-H. The emerging role of long non-coding RNAs in the drug resistance of colorectal cancer. Int. J. Clin. Exp. Pathol. 2018, 11, 4735-4743.

98. Deng, J.-J.; Zhang, W.; Xu, X.-M.; Zhang, F.; Tao, W.-P.; Ye, J.-J.; Ge, W. Twist mediates an aggressive phenotype in human colorectal cancer cells. Int. J. Oncol. 2016, 48, 1117-1124. [CrossRef]

99. Francescangeli, F.; Contavalli, P.; De Angelis, M.L.; Careccia, S.; Signore, M.; Haas, T.L.; Salaris, F.; Baiocchi, M.; Boe, A.; Giuliani, A.; et al. A pre-existing population of ZEB2+ quiescent cells with stemness and mesenchymal features dictate chemoresistance in colorectal cancer. J. Exp. Clin. Cancer Res. 2020, 39, 2. [CrossRef]

100. Mohd-Zahid, M.H.; Mohamud, R.; Che Abdullah, C.A.; Lim, J.; Alem, H.; Wan Hanaffi, W.N.; Iskandar, Z.A. Colorectal cancer stem cells: A review of targeted drug delivery by gold nanoparticles. RSC Adv. 2020, 10, 973-985. [CrossRef]

101. Iyer, D.N.; Sin, W.-Y.; Ng, L. Linking stemness with colorectal cancer initiation, progression, and therapy. World J. Stem Cells 2019, 11, 519-534. [CrossRef]

102. Quarni, W.; Dutta, R.; Green, R.; Katiri, S.; Patel, B.; Mohapatra, S.S.; Mohapatra, S. Mithramycin A Inhibits Colorectal Cancer Growth by Targeting Cancer Stem Cells. Sci. Rep. 2019, 9, 15202. [CrossRef] [PubMed]

103. Jahanafrooz, Z.; Mosafer, J.; Akbari, M.; Hashemzaei, M.; Mokhtarzadeh, A.; Baradaran, B. Colon cancer therapy by focusing on colon cancer stem cells and their tumor microenvironment. J. Cell. Physiol. 2020, 235, 4153-4166. [CrossRef] [PubMed]

104. Chen, J.; Zhao, J.; Ding, J.; Wang, Z.; Du, J.; Wu, C. Knocking down LSD1 inhibits the stemness features of colorectal cancer stem cells. Braz. J. Med. Biol. Res. 2020, 53, e9230. [CrossRef] [PubMed]

105. Chen, W.; Dong, J.; Haiech, J.; Kilhoffer, M.-C.; Zeniou, M. Cancer Stem Cell Quiescence and Plasticity as Major Challenges in Cancer Therapy. Stem Cells Int. 2016, 2016, 1740936. [CrossRef] [PubMed]

106. Trisciuoglio, D.; Tupone, M.G.; Desideri, M.; Di Martile, M.; Gabellini, C.; Buglioni, S.; Pallocca, M.; Alessandrini, G.; D'Aguanno, S.; Del Bufalo, D. BCL-XL overexpression promotes tumor progression-associated properties. Cell Death Dis. 2017, 8, 3216. [CrossRef] [PubMed]

107. Zhou, Y.; Xia, L.; Wang, H.; Oyang, L.; Su, M.; Liu, Q.; Lin, J.; Tan, S.; Tian, Y.; Liao, Q.; et al. Cancer stem cells in progression of colorectal cancer. Oncotarget 2017, 9, 33403-33415. [CrossRef]

108. Begicevic, R.-R.; Falasca, M. ABC Transporters in Cancer Stem Cells: Beyond Chemoresistance. Int. J. Mol. Sci. 2017, 18, 2362. [CrossRef] 
109. Kim, E.; Davidson, L.A.; Zoh, R.S.; Hensel, M.E.; Patil, B.S.; Jayaprakasha, G.K.; Callaway, E.S.; Allred, C.D.; Turner, N.D.; Weeks, B.R.; et al. Homeostatic responses of colonic LGR5+ stem cells following acute in vivo exposure to a genotoxic carcinogen. Carcinogenesis 2016, 37, 206-214. [CrossRef]

110. Das, P.; Islam, M.; Lam, A. The Roles of Cancer Stem Cells and Therapy Resistance in Colorectal Carcinoma. Cells 2020, 9 , 1392. [CrossRef]

111. Steinbichler, T.B.; Dudás, J.; Skvortsov, S.; Ganswindt, U.; Riechelmann, H.; Skvortsova, I.-I. Therapy resistance mediated by cancer stem cells. Semin. Cancer Biol. 2018, 53, 156-167. [CrossRef] [PubMed]

112. Wang, J.; Wang, W.; Cai, H.; Du, B.; Zhang, L.; Ma, W.; Hu, Y.; Feng, S.; Miao, G. MACC1 facilitates chemoresistance and cancer stem cell-like properties of colon cancer cells through the PI3K/AKT signaling pathway. Mol. Med. Rep. 2017, 16, 8747-8754 [CrossRef] [PubMed]

113. Kim, E.-J.; Kang, G.-J.; Kang, J.-I.; Boo, H.-J.; Hyun, J.W.; Koh, Y.S.; Chang, W.-Y.; Kim, Y.R.; Kwon, J.-M.; Maeng, Y.H.; et al. Over-activation of AKT signaling leading to 5-Fluorouracil resistance in SNU-C5/5-FU cells. Oncotarget 2018, 9, 19911-19928. [CrossRef] [PubMed]

114. Cheng, X.; Xu, X.; Chen, D.; Zhao, F.; Wang, W. Therapeutic potential of targeting the Wnt/ $\beta$-catenin signaling pathway in colorectal cancer. Biomed. Pharmacother. 2019, 110, 473-481. [CrossRef] [PubMed]

115. Urushibara, S.; Tsubota, T.; Asai, R.; Azumi, J.; Ashida, K.; Fujiwara, Y.; Shiota, G. WNT/ $\beta$-Catenin Signaling Inhibitor IC-2 Suppresses Sphere Formation and Sensitizes Colorectal Cancer Cells to 5-Fluorouracil. Anticancer Res. 2017, 37, 4085-4091.

116. Dermani, F.K.; Amini, R.; Saidijam, M.; Pourjafar, M.; Saki, S.; Najafi, R. Zerumbone inhibits epithelial-mesenchymal transition and cancer stem cells properties by inhibiting the $\beta$-catenin pathway through miR-200c. J. Cell. Physiol. 2018, 233, 9538-9547. [CrossRef]

117. Todaro, M.; Alea, M.P.; Di Stefano, A.B.; Cammareri, P.; Vermeulen, L.; Iovino, F.; Tripodo, C.; Russo, A.; Gulotta, G.; Medema, J.P.; et al. Colon cancer stem cells dictate tumor growth and resist cell death by production of interleukin-4. Cell Stem Cell 2007, 1, 389-402. [CrossRef]

118. Tsunekuni, K.; Konno, M.; Haraguchi, N.; Koseki, J.; Asai, A.; Matsuoka, K.; Kobunai, T.; Takechi, T.; Doki, Y.; Mori, M.; et al. CD44/CD133-Positive Colorectal Cancer Stem Cells are Sensitive to Trifluridine Exposure. Sci. Rep. 2019, 9, 14861. [CrossRef]

119. Vincent, A.; Ouelkdite-Oumouchal, A.; Souidi, M.; Leclerc, J.; Neve, B.; Van Seuningen, I. Colon cancer stemness as a reversible epigenetic state: Implications for anticancer therapies. World J. Stem Cells 2019, 11, 920-936. [CrossRef]

120. Paschall, A.V.; Yang, D.; Lu, C.; Redd, P.S.; Choi, J.-H.; Heaton, C.M.; Lee, J.R.; Nayak-Kapoor, A.; Liu, K. CD133 ${ }^{+}$CD24 ${ }^{\text {lo }}$ defines a 5-Fluorouracil-resistant colon cancer stem cell-like phenotype. Oncotarget 2016, 7, 78698-78712. [CrossRef]

121. Park, Y.Y.; An, C.H.; Oh, S.T.; Chang, E.D.; Lee, J. Expression of CD133 is associated with poor prognosis in stage II colorectal carcinoma. Medicine 2019, 98, e16709. [CrossRef]

122. Miller, T.J.; McCoy, M.J.; Hemmings, C.; Bulsara, M.K.; Iacopetta, B.; Platell, C.F. The prognostic value of cancer stem-like cell markers SOX2 and CD133 in stage III colon cancer is modified by expression of the immune-related markers FoxP3, PD-L1 and CD3. Pathology 2017, 49, 721-730. [CrossRef]

123. Márquez-González, R.M.; Saucedo-Sariñana, A.M.; Barros-Núñez, P.; Gallegos-Arreola, M.P.; Pineda-Razo, T.D.; Marin-Contreras, M.E.; Flores-Martínez, S.E.; Sánchez-Corona, J.; Rosales-Reynoso, M.A. CD44 Genotypes Are Associated with Susceptibility and Tumor Characteristics in Colorectal Cancer Patients. Tohoku J. Exp. Med. 2020, 250, 109-119. [CrossRef] [PubMed]

124. Wang, Z.; Tang, Y.; Xie, L.; Huang, A.; Xue, C.; Gu, Z.; Wang, K.; Zong, S. The Prognostic and Clinical Value of CD44 in Colorectal Cancer: A Meta-Analysis. Front. Oncol. 2019, 9, 309. [CrossRef] [PubMed]

125. Eom, D.-W.; Hong, S.-M.; Kim, G.; Bae, Y.K.; Jang, K.-T.; Yu, E. Prognostic Significance of CD44v6, CD133, CD166, and ALDH1 Expression in Small Intestinal Adenocarcinoma. Appl. Immunohistochem. Mol. Morphol. AIMM 2015, 23, 682-688. [CrossRef]

126. Kozovska, Z.; Patsalias, A.; Bajzik, V.; Durinikova, E.; Demkova, L.; Jargasova, S.; Smolkova, B.; Plava, J.; Kucerova, L.; Matuskova, M. ALDH1A inhibition sensitizes colon cancer cells to chemotherapy. BMC Cancer 2018, 18, 656. [CrossRef] [PubMed]

127. Sivamaruthi, B.S.; Kesika, P.; Chaiyasut, C. The Role of Probiotics in Colorectal Cancer Management. Evid. Based Complement. Altern. Med. 2020, 2020, 3535982. [CrossRef] [PubMed]

128. An, J.; Ha, E.-M. Combination Therapy of Lactobacillus plantarum Supernatant and 5-Fluouracil Increases Chemosensitivity in Colorectal Cancer Cells. J. Microbiol. Biotechnol. 2016, 26, 1490-1503. [CrossRef] [PubMed]

129. Olmeda, F.; Ben Amar, M. Clonal pattern dynamics in tumor: The concept of cancer stem cells. Sci. Rep. 2019, 9, 15607. [CrossRef]

130. Dominijanni, A.; Gmeiner, W.H. Improved potency of F10 relative to 5-fluorouracil in colorectal cancer cells with p53 mutations. Cancer Drug Resist. 2018, 1, 48-58. [CrossRef]

131. Huang, Y.-C.; Li, Z.; Li, J.; Lyu, F.-J. Interaction between Stem Cells and the Microenvironment for Musculoskeletal Repair. Stem Cells Int. 2020, 2020, 7587428. [CrossRef] [PubMed]

132. Li, Z.-L.; Wang, Z.-J.; Wei, G.-H.; Yang, Y.; Wang, X.-W. Changes in extracellular matrix in different stages of colorectal cancer and their effects on proliferation of cancer cells. World J. Gastrointest. Oncol. 2020, 12, 267-275. [CrossRef]

133. Manmuan, S.; Manmuan, P. Fucoxanthin enhances 5-FU chemotherapeutic efficacy in colorectal cancer cells by affecting MMP-9 invasive proteins. J. Appl. Pharm. Sci. 2019, 9, 7-14. 
134. Bauer, J.; Emon, M.A.B.; Staudacher, J.J.; Thomas, A.L.; Zessner-Spitzenberg, J.; Mancinelli, G.; Krett, N.; Saif, M.T.; Jung, B. Increased stiffness of the tumor microenvironment in colon cancer stimulates cancer associated fibroblast-mediated prometastatic activin A signaling. Sci. Rep. 2020, 10, 50. [CrossRef] [PubMed]

135. Wang, S.; Miao, Z.; Yang, Q.; Wang, Y.; Zhang, J. The Dynamic Roles of Mesenchymal Stem Cells in Colon Cancer. Can. J. Gastroenterol. Hepatol. 2018, 2018, 7628763. [CrossRef]

136. Herrera, M.; Galindo-Pumariño, C.; García-Barberán, V.; Peña, C. A Snapshot of The Tumor Microenvironment in Colorectal Cancer: The Liquid Biopsy. Int. J. Mol. Sci. 2019, 20, 6016. [CrossRef]

137. Wei, R.; Liu, S.; Zhang, S.; Min, L.; Zhu, S. Cellular and Extracellular Components in Tumor Microenvironment and Their Application in Early Diagnosis of Cancers. Anal. Cell. Pathol. 2020, 2020, 6283796. [CrossRef]

138. Yahaya, M.A.F.; Lila, M.A.M.; Ismail, S.; Zainol, M.; Afizan, N.A.R.N.M. Tumour-Associated Macrophages (TAMs) in Colon Cancer and How to Reeducate Them. J. Immunol. Res. 2019, 2019, 2368249. [CrossRef]

139. Zhong, X.; Chen, B.; Yang, Z. The Role of Tumor-Associated Macrophages in Colorectal Carcinoma Progression. Cell. Physiol. Biochem. 2018, 45, 356-365. [CrossRef]

140. Ben-Shmuel, A.; Biber, G.; Barda-Saad, M. Unleashing Natural Killer Cells in the Tumor Microenvironment-The Next Generation of Immunotherapy? Front. Immunol. 2020, 11, 275. [CrossRef]

141. Bassani, B.; Baci, D.; Gallazzi, M.; Poggi, A.; Bruno, A.; Mortara, L. Natural Killer Cells as Key Players of Tumor Progression and Angiogenesis: Old and Novel Tools to Divert Their Pro-Tumor Activities into Potent Anti-Tumor Effects. Cancers 2019, 11, 461. [CrossRef]

142. Guo, G.; Wang, Y.; Zhou, Y.; Quan, Q.; Zhang, Y.; Wang, H.; Zhang, B.; Xia, L. Immune cell concentrations among the primary tumor microenvironment in colorectal cancer patients predicted by clinicopathologic characteristics and blood indexes. J. Immunother. Cancer 2019, 7, 179. [CrossRef] [PubMed]

143. Xiong, Y.; Wang, Y.; Tiruthani, K. Tumor immune microenvironment and nano-immunotherapeutics in colorectal cancer. Nanomed. Nanotechnol. Biol. Med. 2019, 21, 102034. [CrossRef]

144. Guo, F.F.; Cui, J.W. The Role of Tumor-Infiltrating B Cells in Tumor Immunity. J. Oncol. 2019, 2019, 2592419. [CrossRef]

145. Zhang, G.; Luo, X.; Zhang, W.; Chen, E.; Xu, J.; Wang, F.; Cao, G.; Ju, Z.; Jin, D.; Huang, X.; et al. CXCL-13 Regulates Resistance to 5-Fluorouracil in Colorectal Cancer. Cancer Res. Treat. 2020, 52, 622-633. [CrossRef]

146. Kazanietz, M.G.; Durando, M.; Cooke, M. CXCL13 and Its Receptor CXCR5 in Cancer: Inflammation, Immune Response, and Beyond. Front. Endocrinol. 2019, 10, 471. [CrossRef]

147. Zhu, Z.; Zhang, X.; Guo, H.; Fu, L.; Pan, G.; Sun, Y. CXCL13-CXCR5 axis promotes the growth and invasion of colon cancer cells via PI3K/AKT pathway. Mol. Cell. Biochem. 2015, 400, 287-295. [CrossRef]

148. Yu, X.; Shi, W.; Zhang, Y.; Wang, X.; Sun, S.; Song, Z.; Liu, M.; Zeng, Q.; Cui, S.; Qu, X. CXCL12/CXCR4 axis induced miR-125b promotes invasion and confers 5-fluorouracil resistance through enhancing autophagy in colorectal cancer. Sci. Rep. 2017, 7, 42226. [CrossRef]

149. Huang, W.-S.; Hsieh, M.-C.; Huang, C.-Y.; Kuo, Y.-H.; Tung, S.-Y.; Shen, C.-H.; Hsieh, Y.-Y.; Teng, C.-C.; Lee, K.-F.; Chen, T.-C.; et al. The Association of CXC Receptor 4 Mediated Signaling Pathway with Oxaliplatin-Resistant Human Colorectal Cancer Cells. PLoS ONE 2016, 11, e0159927. [CrossRef]

150. Ma, J.; Sun, X.; Wang, Y.; Chen, B.; Qian, L.; Wang, Y. Fibroblast-derived CXCL12 regulates PTEN expression and is associated with the proliferation and invasion of colon cancer cells via PI3k/Akt signaling. Cell Commun. Signal. 2019, 17, 119. [CrossRef]

151. Wang, D.; Yang, L.; Yu, W.; Wu, Q.; Lian, J.; Li, F.; Liu, S.; Li, A.; He, Z.; Liu, J.; et al. Colorectal cancer cell-derived CCL20 recruits regulatory $\mathrm{T}$ cells to promote chemoresistance via FOXO1/CEBPB/NF- $\mathrm{kB}$ signaling. J. Immunother. Cancer 2019, 7, 215. [CrossRef] [PubMed]

152. Romano, G.; Santi, L.; Bianco, M.R.; Giuffrè, M.R.; Pettinato, M.; Bugarin, C.; Garanzini, C.; Savarese, L.; Leoni, S.; Cerrito, M.G.; et al. The TGF- $\beta$ pathway is activated by 5 -fluorouracil treatment in drug resistant colorectal carcinoma cells. Oncotarget 2016, 7 , 22077-22091. [CrossRef] [PubMed]

153. Wei, C.; Yang, C.; Wang, S.; Shi, D.; Zhang, C.; Lin, X.; Xiong, B. M2 macrophages confer resistance to 5-fluorouracil in colorectal cancer through the activation of CCL22/PI3K/AKT signaling. Onco Targets Ther. 2019, 12, 3051-3063. [CrossRef]

154. Jayasingam, S.D.; Citartan, M.; Thang, T.H.; Mat Zin, A.A.; Ang, K.C.; Ch'ng, E.S. Evaluating the Polarization of Tumor-Associated Macrophages Into M1 and M2 Phenotypes in Human Cancer Tissue: Technicalities and Challenges in Routine Clinical Practice. Front. Oncol. 2020, 9, 1512. [CrossRef]

155. Malesci, A.; Bianchi, P.; Celesti, G.; Basso, G.; Marchesi, F.; Grizzi, F.; Di Caro, G.; Cavalleri, T.; Rimassa, L.; Palmqvist, R.; et al. Tumor-associated macrophages and response to 5-fluorouracil adjuvant therapy in stage III colorectal cancer. Oncoimmunology 2017, 6, e1342918. [CrossRef]

156. Liu, T.; Han, C.; Wang, S.; Fang, P.; Ma, Z.; Xu, L.; Yin, R. Cancer-associated fibroblasts: An emerging target of anti-cancer immunotherapy. J. Hematol. Oncol. 2019, 12, 86. [CrossRef]

157. Gonçalves-Ribeiro, S.; Díaz-Maroto, N.G.; Berdiel-Acer, M.; Soriano, A.; Guardiola, J.; Martínez-Villacampa, M.; Salazar, R.; Capellà, G.; Villanueva, A.; Martínez-Balibrea, E.; et al. Carcinoma-associated fibroblasts affect sensitivity to oxaliplatin and 5FU in colorectal cancer cells. Oncotarget 2016, 7, 59766-59780. [CrossRef] 
158. Yadav, V.K.; Huang, Y.-J.; George, T.A.; Wei, P.-L.; Sumitra, M.R.; Ho, C.-L.; Chang, T.-H.; Wu, A.T.H.; Huang, H.-S. Preclinical Evaluation of the Novel Small-Molecule MSI-N1014 for Treating Drug-Resistant Colon Cancer via the LGR5/ $\beta$-catenin/miR-142$3 p$ Network and Reducing Cancer-Associated Fibroblast Transformation. Cancers 2020, 12, 1590. [CrossRef]

159. Zhang, R.; Qi, F.; Zhao, F.; Li, G.; Shao, S.; Zhang, X.; Yuan, L.; Feng, Y. Cancer-associated fibroblasts enhance tumor-associated macrophages enrichment and suppress NK cells function in colorectal cancer. Cell Death Dis. 2019, 10, 273. [CrossRef]

160. Liu, M.-L.; Zang, F.; Zhang, S.-J. RBCK1 contributes to chemoresistance and stemness in colorectal cancer (CRC). Biomed. Pharmacother. 2019, 118, 109250. [CrossRef]

161. Koh, B.; Jeon, H.; Kim, D.; Kang, D.; Kim, K.R. Effect of fibroblast co-culture on the proliferation, viability and drug response of colon cancer cells. Oncol. Lett. 2019, 17, 2409-2417. [CrossRef] [PubMed]

162. Yoshida, G.J. Regulation of heterogeneous cancer-associated fibroblasts: The molecular pathology of activated signaling pathways. J. Exp. Clin. Cancer Res. 2020, 39, 112. [CrossRef] [PubMed]

163. Hu, Y.; Yan, C.; Mu, L.; Huang, K.; Li, X.; Tao, D.; Wu, Y.; Qin, J. Fibroblast-Derived Exosomes Contribute to Chemoresistance through Priming Cancer Stem Cells in Colorectal Cancer. PLoS ONE 2015, 10, e0125625. [CrossRef]

164. Zhang, Q.; Liu, R.-X.; Chan, K.-W.; Hu, J.; Zhang, J.; Wei, L.; Tan, H.; Yang, X.; Liu, H. Exosomal transfer of p-STAT3 promotes acquired 5-FU resistance in colorectal cancer cells. J. Exp. Clin. Cancer Res. 2019, 38, 320. [CrossRef]

165. Hu, Y.-B.; Yan, C.; Mu, L.; Mi, Y.-L.; Zhao, H.; Hu, H.; Li, X.-L.; Tao, D.-D.; Wu, Y.-Q.; Gong, J.-P.; et al. Exosomal Wnt-induced dedifferentiation of colorectal cancer cells contributes to chemotherapy resistance. Oncogene 2019, 38, 1951-1965. [CrossRef]

166. Hon, K.W.; Ab-Mutalib, N.S.; Abdullah, N.M.A.; Jamal, R.; Abu, N. Extracellular Vesicle-derived circular RNAs confers chemoresistance in Colorectal cancer. Sci. Rep. 2019, 9, 16497. [CrossRef] [PubMed]

167. Bigagli, E.; Luceri, C.; Guasti, D.; Cinci, L. Exosomes secreted from human colon cancer cells influence the adhesion of neighboring metastatic cells: Role of microRNA-210. Cancer Biol. Ther. 2016, 17, 1062-1069. [CrossRef] [PubMed]

168. Sun, L.-H.; Tian, D.; Yang, Z.-C.; Li, J.-L. Exosomal miR-21 promotes proliferation, invasion and therapy resistance of colon adenocarcinoma cells through its target PDCD4. Sci. Rep. 2020, 10, 8271. [CrossRef]

169. Shinohara, H.; Kuranaga, Y.; Kumazaki, M.; Sugito, N.; Yoshikawa, Y.; Takai, T.; Taniguchi, K.; Ito, Y.; Akao, Y. Regulated Polarization of Tumor-Associated Macrophages by miR-145 via Colorectal Cancer-Derived Extracellular Vesicles. J. Immunol. 2017, 199, 1505-1515. [CrossRef]

170. Xiao, Y.; Li, Y.; Yuan, Y.; Liu, B.; Pan, S.; Liu, Q.; Qi, X.; Zhou, H.; Dong, W.; Jia, L. The potential of exosomes derived from colorectal cancer as a biomarker. Clin. Chim. Acta 2019, 490, 186-193. [CrossRef]

171. Handy, D.E.; Castro, R.; Loscalzo, J. Epigenetic modifications: Basic mechanisms and role in cardiovascular disease. Circulation 2011, 123, 2145-2156. [CrossRef] [PubMed]

172. Babaei, K.; Khaksar, R.; Zeinali, T.; Hemmati, H.; Bandegi, A.; Samidoust, P.; Ashoobi, M.T.; Hashemian, H.; Delpasand, K.; Talebinasab, F.; et al. Epigenetic profiling of MUTYH, KLF6, WNT1 and KLF4 genes in carcinogenesis and tumorigenesis of colorectal cancer. BioMedicine 2019, 9, 22. [CrossRef]

173. Cheng, Y.; He, C.; Wang, M.; Ma, X.; Mo, F.; Yang, S.; Han, J.; Wei, X. Targeting epigenetic regulators for cancer therapy: Mechanisms and advances in clinical trials. Signal Transduct. Target. Ther. 2019, 4, 62. [CrossRef]

174. Zhang, H.; Lu, Y.; Wu, J.; Feng, J. LINC00460 Hypomethylation Promotes Metastasis in Colorectal Carcinoma. Front. Genet. 2019, 10, 880. [CrossRef]

175. Zhang, H.; Sun, X.; Lu, Y.; Wu, J.; Feng, J. DNA-methylated gene markers for colorectal cancer in TCGA database. Exp. Ther. Med. 2020, 19, 3042-3050. [CrossRef]

176. Shen, Y.; Tong, M.; Liang, Q.; Guo, Y.; Sun, H.Q.; Zheng, W.; Ao, L.; Guo, Z.; She, F. Epigenomics alternations and dynamic transcriptional changes in responses to 5-fluorouracil stimulation reveal mechanisms of acquired drug resistance of colorectal cancer cells. Pharm. J. 2018, 18, 23-28. [CrossRef]

177. Shi, L.; Li, X.; Wu, Z.; Li, X.; Nie, J.; Guo, M.; Mei, Q.; Han, W. DNA methylation-mediated repression of miR-181a/135a/302c expression promotes the microsatellite-unstable colorectal cancer development and 5-FU resistance via targeting PLAG1. J. Genet. Genom. 2018, 45, 205-214. [CrossRef]

178. He, J.; Pei, L.; Jiang, H.; Yang, W.; Chen, J.; Liang, H. Chemoresistance of colorectal cancer to 5-fluorouracil is associated with silencing of the BNIP3 gene through aberrant methylation. J. Cancer 2017, 8, 1187-1196. [CrossRef]

179. Wang, B.; Lu, F.-Y.; Shi, R.-H.; Feng, Y.-D.; Zhao, X.-D.; Lu, Z.-P.; Xiao, L.; Zhou, G.-Q.; Qiu, J.-M.; Cheng, C.-E. MiR-26b regulates 5-FU-resistance in human colorectal cancer via down-regulation of Pgp. Am. J. Cancer Res. 2018, 8, 2518-2527.

180. Fouad, M.A.; Salem, S.E.; Hussein, M.M.; Zekri, A.R.N.; Hafez, H.F.; El Desouky, E.D.; Shouman, S.A. Impact of Global DNA Methylation in Treatment Outcome of Colorectal Cancer Patients. Front. Pharmacol. 2018, 9, 1173. [CrossRef]

181. Baharudin, R.; Ab Mutalib, N.-S.; Othman, S.N.; Sagap, I.; Rose, I.M.; Mohd Mokhtar, N.; Jamal, R. Identification of Predictive DNA Methylation Biomarkers for Chemotherapy Response in Colorectal Cancer. Front. Pharmacol. 2017, 8, 47. [CrossRef] [PubMed]

182. Chang, S.; Huang, J.; Niu, H.; Wang, J.; Si, Y.; Bai, Z.; Ding, W. Epigenetic regulation of osteopontin splicing isoform c defines its role as a microenvironmental factor to promote the survival of colon cancer cells from 5-FU treatment. Res. Sq 2020. [CrossRef]

183. Jiang, G.; Lin, J.; Wang, W.; Sun, M.; Chen, K.; Wang, F. WNT5A Promoter Methylation Is Associated with Better Responses and Longer Progression-Free Survival in Colorectal Cancer Patients Treated with 5-Fluorouracil-Based Chemotherapy. Genet. Test. Mol. Biomark. 2017, 21, 74-79. [CrossRef] 
184. Wen, S.; Wang, X.; Wang, Y.; Shen, J.; Pu, J.; Liang, H.; Chen, C.; Liu, L.; Dai, P. Nucleoside diphosphate kinase 2 confers acquired 5-fluorouracil resistance in colorectal cancer cells. Artif. Cells Nanomed. Biotechnol. 2018, 46, 896-905. [CrossRef] [PubMed]

185. Paschall, A.V.; Yang, D.; Lu, C.; Choi, J.-H.; Li, X.; Liu, F.; Figueroa, M.; Oberlies, N.H.; Pearce, C.; Bollag, W.B.; et al. H3K9 Trimethylation Silences Fas Expression To Confer Colon Carcinoma Immune Escape and 5-Fluorouracil Chemoresistance. J. Immunol. 2015, 195, 1868-1882. [CrossRef]

186. Zhan, W.; Liao, X.; Liu, J.; Tian, T.; Yu, L.; Li, R. USP38 regulates the stemness and chemoresistance of human colorectal cancer via regulation of HDAC3. Oncogenesis 2020, 9, 48. [CrossRef]

187. Moody, L.; Dvoretskiy, S.; An, R.; Mantha, S.; Pan, Y.-X. The Efficacy of miR-20a as a Diagnostic and Prognostic Biomarker for Colorectal Cancer: A Systematic Review and Meta-Analysis. Cancers 2019, 11, 1111. [CrossRef]

188. Perilli, L.; Tessarollo, S.; Albertoni, L.; Curtarello, M.; Pastò, A.; Brunetti, E.; Fassan, M.; Rugge, M.; Indraccolo, S.; Amadori, A.; et al. Silencing of miR-182 is associated with modulation of tumorigenesis through apoptosis induction in an experimental model of colorectal cancer. BMC Cancer 2019, 19, 821. [CrossRef]

189. Li, H.; Zhang, X.; Jin, Z.; Yin, T.; Duan, C.; Sun, J.; Xiong, R.; Li, Z. MiR-122 Promotes the Development of Colon Cancer by Targeting ALDOA in Vitro. Technol. Cancer Res. Treat. 2019, 18, 1533033819871300. [CrossRef]

190. Angius, A.; Pira, G.; Scanu, A.M.; Uva, P.; Sotgiu, G.; Saderi, L.; Manca, A.; Serra, C.; Uleri, E.; Piu, C.; et al. MicroRNA-425-5p Expression Affects BRAF/RAS/MAPK Pathways In Colorectal Cancers. Int. J. Med. Sci. 2019, 16, 1480-1491. [CrossRef]

191. Mukohyama, J.; Isobe, T.; Hu, Q.; Hayashi, T.; Watanabe, T.; Maeda, M.; Yanagi, H.; Qian, X.; Yamashita, K.; Minami, H.; et al miR-221 targets QKI to enhance the tumorigenic capacity of human colorectal cancer stem cells. Cancer Res. 2019, 79, 5151-5158. [CrossRef] [PubMed]

192. Carter, V.J.; O’brien, J.S.; Burton, F.J.; Oxford, G.B.; Stephen, V.; Hallion, J.; Bishop, C.; Galbraith, J.N.; Eichenberger, R.M.; Sarojini, H.; et al. The microRNA-200 family acts as an oncogene in colorectal cancer by inhibiting the tumor suppressor RASSF2. Oncol. Lett. 2019, 18, 3994-4007. [CrossRef] [PubMed]

193. Tang, X.; Shi, X.; Wang, N.; Peng, W.; Cheng, Z. MicroRNA-215-3p Suppresses the Growth, Migration, and Invasion of Colorectal Cancer by Targeting FOXM1. Technol. Cancer Res. Treat. 2019, 18, 1533033819874776. [CrossRef]

194. Gu, C.; Cai, J.; Xu, Z.; Zhou, S.; Ye, L.; Yan, Q.; Zhang, Y.; Fang, Y.; Liu, Y.; Tu, C.; et al. MiR-532-3p suppresses colorectal cancer progression by disrupting the ETS1/TGM2 axis-mediated Wnt/ $\beta$-catenin signaling. Cell Death Dis. 2019, 10, 739. [CrossRef] [PubMed]

195. Fang, Y.; Yang, C.; Zhang, L.; Wei, L.; Lin, J.; Zhao, J.; Peng, J. Spica Prunellae Extract Enhances Fluorouracil Sensitivity of 5-Fluorouracil-Resistant Human Colon Carcinoma HCT-8/5-FU Cells via TOP2 $\alpha$ and miR-494. Biomed. Res. Int. 2019, 2019, 5953619. [CrossRef]

196. Nowak-Sliwinska, P.; Scapozza, L.; Ruiz i Altaba, A. Drug repurposing in oncology: Compounds, pathways, phenotypes and computational approaches for colorectal cancer. Biochim. Biophys. Acta Rev. Cancer 2019, 1871, 434-454. [CrossRef]

197. Zhang, L.; Li, B.; Zhang, B.; Zhang, H.; Suo, J. miR-361 enhances sensitivity to 5-fluorouracil by targeting the FOXM1-ABCC5/10 signaling pathway in colorectal cancer. Oncol. Lett. 2019, 18, 4064-4073. [CrossRef]

198. Barisciano, G.; Colangelo, T.; Rosato, V.; Muccillo, L.; Taddei, M.L.; Ippolito, L.; Chiarugi, P.; Galgani, M.; Bruzzaniti, S.; Matarese, G.; et al. miR-27a is a master regulator of metabolic reprogramming and chemoresistance in colorectal cancer. $\mathrm{Br}$. $\mathrm{J}$. Cancer 2020, 122, 1354-1366. [CrossRef]

199. Karimi Dermani, F.; Najafi, R. miR-200c as a Predictive Biomarker for 5-Fluorouracil Chemosensitivity in Colorectal Cancer. J. Gastrointest. Cancer 2018, 49, 102-103. [CrossRef]

200. Zhang, Y.; Talmon, G.; Wang, J. MicroRNA-587 antagonizes 5-FU-induced apoptosis and confers drug resistance by regulating PPP2R1B expression in colorectal cancer. Cell Death Dis. 2015, 6, e1845. [CrossRef]

201. Zhang, H.; Tang, J.; Li, C.; Kong, J.; Wang, J.; Wu, Y.; Xu, E.; Lai, M. MiR-22 regulates 5-FU sensitivity by inhibiting autophagy and promoting apoptosis in colorectal cancer cells. Cancer Lett. 2014, 356. [CrossRef] [PubMed]

202. Xu, F.; Ye, M.-L.; Zhang, Y.-P.; Li, W.-J.; Li, M.-T.; Wang, H.-Z.; Qiu, X.; Xu, Y.; Yin, J.-W.; Hu, Q.; et al. MicroRNA-375-3p enhances chemosensitivity to 5-fluorouracil by targeting thymidylate synthase in colorectal cancer. Cancer Sci. 2020, 111, $1528-1541$. [CrossRef] [PubMed]

203. Ren, T.-J.; Liu, C.; Hou, J.-F.; Shan, F.-X. CircDDX17 reduces 5-fluorouracil resistance and hinders tumorigenesis in colorectal cancer by regulating miR-31-5p/KANK1 axis. Eur. Rev. Med. Pharmacol. Sci. 2020, 24, 1743-1754. [CrossRef] [PubMed]

204. Wu, H.; Liang, Y.; Shen, L.; Shen, L. MicroRNA-204 modulates colorectal cancer cell sensitivity in response to 5-fluorouracil-based treatment by targeting high mobility group protein A2. Biol. Open 2016, 5, 563-570. [CrossRef]

205. Yang, Y.; Bao, Y.; Yang, G.-K.; Wan, J.; Du, L.-J.; Ma, Z.-H. MiR-214 sensitizes human colon cancer cells to 5-FU by targeting Hsp27. Cell. Mol. Biol. Lett. 2019, 24, 22. [CrossRef]

206. Liu, G.; Zhou, J.; Dong, M. Down-regulation of miR-543 expression increases the sensitivity of colorectal cancer cells to 5Fluorouracil through the PTEN/PI3K/AKT pathway. Biosci. Rep. 2019, 39. [CrossRef]

207. Zhao, C.; Zhao, Q.; Zhang, C.; Wang, G.; Yao, Y.; Huang, X.; Zhan, F.; Zhu, Y.; Shi, J.; Chen, J.; et al. miR-15b-5p resensitizes colon cancer cells to 5-fluorouracil by promoting apoptosis via the NF-кB/XIAP axis. Sci. Rep. 2017, 7, 4194. [CrossRef]

208. Liu, J.; Huang, Y.; Wang, H.; Wu, D. MiR-106a-5p promotes 5-FU resistance and the metastasis of colorectal cancer by targeting TGFßR2. Int. J. Clin. Exp. Pathol. 2018, 11, 5622-5634. 
209. Meng, X.; Fu, R. miR-206 regulates 5-FU resistance by targeting Bcl-2 in colon cancer cells. Onco Targets Ther. 2018, 11, 1757-1765. [CrossRef]

210. Park, G.-B.; Jeong, J.-Y.; Kim, D. Modified TLR-mediated downregulation of miR-125b-5p enhances CD248 (endosialin)-induced metastasis and drug resistance in colorectal cancer cells. Mol. Carcinog. 2020, 59, 154-167. [CrossRef]

211. Xu, G.; Zhu, H.; Xu, J.; Wang, Y.; Zhang, Y.; Zhang, M.; Zhu, D. Long non-coding RNA POU6F2-AS2 promotes cell proliferation and drug resistance in colon cancer by regulating miR-377/BRD4. J. Cell. Mol. Med. 2020, 24, 4136-4149. [CrossRef] [PubMed]

212. Bian, Z.; Zhang, J.; Li, M.; Feng, Y.; Yao, S.; Song, M.; Qi, X.; Fei, B.; Yin, Y.; Hua, D.; et al. Long non-coding RNA LINC00152 promotes cell proliferation, metastasis, and confers 5-FU resistance in colorectal cancer by inhibiting miR-139-5p. Oncogenesis 2017, 6, 395. [CrossRef] [PubMed]

213. Sun, W.; Li, J.; Zhou, L.; Han, J.; Liu, R.; Zhang, H.; Ning, T.; Gao, Z.; Liu, B.; Chen, X.; et al. The c-Myc/miR-27b-3p/ATG10 regulatory axis regulates chemoresistance in colorectal cancer. Theranostics 2020, 10, 1981-1996. [CrossRef] [PubMed]

214. PARK, G.-B.; Kim, D. TLR-mediated miR-125b-5p downregulation enhances CD248-induced metastasis and drug resistance in colorectal cancer cells. Cancer Biol. 2019. [CrossRef]

215. Aggarwal, V.; Tuli, H.S.; Varol, A.; Thakral, F.; Yerer, M.B.; Sak, K.; Varol, M.; Jain, A.; Khan, M.A.; Sethi, G. Role of Reactive Oxygen Species in Cancer Progression: Molecular Mechanisms and Recent Advancements. Biomolecules 2019, 9, 735. [CrossRef]

216. Moreira, H.; Szyjka, A.; Paliszkiewicz, K.; Barg, E. Prooxidative Activity of Celastrol Induces Apoptosis, DNA Damage, and Cell Cycle Arrest in Drug-Resistant Human Colon Cancer Cells. Oxid. Med. Cell. Longev. 2019, 2019, 6793957. [CrossRef]

217. Yan, J.; Dou, X.; Zhou, J.; Xiong, Y.; Mo, L.; Li, L.; Lei, Y. Tubeimoside-I sensitizes colorectal cancer cells to chemotherapy by inducing ROS-mediated impaired autophagolysosomes accumulation. J. Exp. Clin. Cancer Res. 2019, 38, 353. [CrossRef]

218. Liu, C.; Zhao, Y.; Wang, J.; Yang, Y.; Zhang, Y.; Qu, X.; Peng, S.; Yao, Z.; Zhao, S.; He, B.; et al. FoxO3 reverses 5-fluorouracil resistance in human colorectal cancer cells by inhibiting the Nrf2/TR1 signaling pathway. Cancer Lett. 2020, 470, 29-42. [CrossRef]

219. Liu, T.; Han, Y.; Yu, C.; Ji, Y.; Wang, C.; Chen, X.; Wang, X.; Shen, J.; Zhang, Y.; Lang, J.-Y. MYC predetermines the sensitivity of gastrointestinal cancer to antifolate drugs through regulating TYMS transcription. EBioMedicine 2019, 48, 289-300. [CrossRef]

220. Turgeon, M.-O.; Perry, N.J.S.; Poulogiannis, G. DNA Damage, Repair, and Cancer Metabolism. Front. Oncol. 2018, 8, 15. [CrossRef]

221. Jiang, H.; Li, B.; Wang, F.; Ma, C.; Hao, T. Expression of ERCC1 and TYMS in colorectal cancer patients and the predictive value of chemotherapy efficacy. Oncol. Lett. 2019, 18, 1157-1162. [CrossRef]

222. Bai, W.; Wu, Y.; Zhang, P.; Xi, Y. Correlations between expression levels of thymidylate synthase, thymidine phosphorylase and dihydropyrimidine dehydrogenase, and efficacy of 5-fluorouracil-based chemotherapy for advanced colorectal cancer. Int. J. Clin. Exp. Pathol. 2015, 8, 12333-12345. [PubMed]

223. Wakasa, K.; Kawabata, R.; Nakao, S.; Hattori, H.; Taguchi, K.; Uchida, J.; Yamanaka, T.; Maehara, Y.; Fukushima, M.; Oda, S. Dynamic Modulation of Thymidylate Synthase Gene Expression and Fluorouracil Sensitivity in Human Colorectal Cancer Cells. PLoS ONE 2015, 10, e0123076. [CrossRef]

224. Showalter, S.L.; Showalter, T.N.; Witkiewicz, A.; Havens, R.; Kennedy, E.P.; Hucl, T.; Kern, S.E.; Yeo, C.J.; Brody, J.R. Evaluating the drug-target relationship between thymidylate synthase expression and tumor response to 5-fluorouracil. Is it time to move forward? Cancer Biol. Ther. 2008, 7, 986-994. [CrossRef] [PubMed]

225. Hammond, W.A.; Swaika, A.; Mody, K. Pharmacologic resistance in colorectal cancer: A review. Ther. Adv. Med. Oncol. 2015, 8, 57-84. [CrossRef] [PubMed]

226. Nie, Q.; Guo, X.; Liu, H.; Zeng, L.; Wang, X.; Wen, S.; Wang, W.; Lu, Y.; Wang, Q.; Peng, W. Effects of DPYD and TS gene polymorphisms on chemosensitivity of 5-FU in advanced colorectal cancer. Int. J. Clin. Exp. Med. 2019, 12, 9380-9386.

227. Ntavatzikos, A.; Spathis, A.; Patapis, P.; Machairas, N.; Vourli, G.; Peros, G.; Papadopoulos, I.; Panayiotides, I.; Koumarianou, A. TYMS/KRAS/BRAF molecular profiling predicts survival following adjuvant chemotherapy in colorectal cancer. World J. Gastrointest. Oncol. 2019, 11, 551-566. [CrossRef]

228. Wang, M.; Hu, H.; Wang, Y.; Huang, Q.; Huang, R.; Chen, Y.; Ma, T.; Qiao, T.; Zhang, Q.; Wu, H.; et al. Long non-coding RNA TUG1 mediates 5-fluorouracil resistance by acting as a ceRNA of miR-197-3p in colorectal cancer. J. Cancer 2019, 10, 4603-4613. [CrossRef]

229. Che, J.; Pan, L.; Yang, X.; Liu, Z.; Huang, L.; Wen, C.; Lin, A.; Liu, H. Thymidine phosphorylase expression and prognosis in colorectal cancer treated with 5-fluorouracil-based chemotherapy: A meta-analysis. Mol. Clin. Oncol. 2017, 7, 943-952. [CrossRef]

230. Kugimiya, N.; Harada, E.; Suehiro, Y.; Suga, A.; Takemoto, Y.; Hamano, K. Determination of thymidine phosphorylase expression level facilitates recurrence risk stratification in stage II/III colorectal cancer following adjuvant chemotherapy with oral fluoropyrimidines. Oncol. Lett. 2019, 17, 5267-5274. [CrossRef]

231. Gajjar, K.K.; Vora, H.H.; Kobawala, T.P.; Trivedi, T.I.; Ghosh, N.R. Deciphering the potential value of 5-fluorouracil metabolic enzymes in predicting prognosis and treatment response of colorectal cancer patients. Int. J. Biol. Markers 2018, 33, 180-188. [CrossRef]

232. Ogawa, M.; Watanabe, M.; Mitsuyama, Y.; Anan, T.; Ohkuma, M.; Kobayashi, T.; Eto, K.; Yanaga, K. Thymidine phosphorylase mRNA expression may be a predictor of response to post-operative adjuvant chemotherapy with S-1 in patients with stage III colorectal cancer. Oncol. Lett. 2014, 8, 2463-2468. [CrossRef]

233. Shigeta, K.; Ishii, Y.; Hasegawa, H.; Okabayashi, K.; Kitagawa, Y. Evaluation of 5-fluorouracil metabolic enzymes as predictors of response to adjuvant chemotherapy outcomes in patients with stage II/III colorectal cancer: A decision-curve analysis. World J. Surg. 2014, 38, 3248-3256. [CrossRef] 
234. Liu, W.; Zhang, J.; Yao, X.; Jiang, C.; Ni, P.; Cheng, L.; Liu, J.; Ni, S.; Chen, Q.; Li, Q.; et al. Bevacizumab-enhanced antitumor effect of 5-fluorouracil via upregulation of thymidine phosphorylase through vascular endothelial growth factor A/vascular endothelial growth factor receptor 2-specificity protein 1 pathway. Cancer Sci. 2018, 109, 3294-3304. [CrossRef]

235. Li, L.-H.; Dong, H.; Zhao, F.; Tang, J.; Chen, X.; Ding, J.; Men, H.-T.; Luo, W.-X.; Du, Y.; Ge, J.; et al. The upregulation of dihydropyrimidine dehydrogenase in liver is involved in acquired resistance to 5-fluorouracil. Eur. J. Cancer 2013, 49, 1752-1760. [CrossRef]

236. Zhang, Y.-H.; Luo, D.-D.; Wan, S.-B.; Qu, X.-J. S1PR2 inhibitors potently reverse 5-FU resistance by downregulating DPD expression in colorectal cancer. Pharmacol. Res. 2020, 155, 104717. [CrossRef]

237. Pathania, S.; Bhatia, R.; Baldi, A.; Singh, R.; Rawal, R.K. Drug metabolizing enzymes and their inhibitors' role in cancer resistance. Biomed. Pharmacother. 2018, 105, 53-65. [CrossRef]

238. Zhang, Y.-H.; Shi, W.-N.; Wu, S.-H.; Miao, R.-R.; Sun, S.-Y.; Luo, D.-D.; Wan, S.-B.; Guo, Z.-K.; Wang, W.-Y.; Yu, X.-F.; et al. SphK2 confers 5-fluorouracil resistance to colorectal cancer via upregulating H3K56ac-mediated DPD expression. Oncogene 2020. [CrossRef]

239. Chen, X.-L.; Wang, Y.-M.; Zhao, F.; Chen, Z.; Yang, X.; Sun, C.; Gao, Y.; Yang, T.-G.; Tian, G.; Chen, Y.-M.; et al. Methylenetetrahydrofolate reductase polymorphisms and colorectal cancer prognosis: A meta-analysis. J. Gene Med. 2019, 21, e3114. [CrossRef]

240. Naghibalhossaini, F.; Shefaghat, M.; Mansouri, A.; Jaberi, H.; Tatar, M.; Eftekhar, E. The Impact of Thymidylate Synthase and Methylenetetrahydrofolate Reductase Genotypes on Sensitivity to 5-Fluorouracil Treatment in Colorectal Cancer Cells. Acta Med. Iran. 2017, 55, 751-758.

241. Pawłowski, P.H.; Szczęsny, P.; Rempoła, B.; Poznańska, A.; Poznański, J. Combined in silico and 19F NMR analysis of 5-fluorouracil metabolism in yeast at low ATP conditions. Biosci. Rep. 2019, 39, BSR20192847. [CrossRef] [PubMed]

242. Tampellini, M.; Bironzo, P.; Di Maio, M.; Scagliotti, G.V. Thymidine phosphorylase: The unforeseen driver in colorectal cancer treatment? Future Oncol. 2018, 14, 1223-1231. [CrossRef] [PubMed]

243. Kumamoto, K.; Kuwabara, K.; Tajima, Y.; Amano, K.; Hatano, S.; Ohsawa, T.; Okada, N.; Ishibashi, K.; Haga, N.; Ishida, H. Thymidylate synthase and thymidine phosphorylase mRNA expression in primary lesions using laser capture microdissection is useful for prediction of the efficacy of FOLFOX treatment in colorectal cancer patients with liver metastasis. Oncol. Lett. 2012, 3, 983-989. [CrossRef] [PubMed]

244. Goto, T.; Shinmura, K.; Yokomizo, K.; Sakuraba, K.; Kitamura, Y.; Shirahata, A.; Saito, M.; Kigawa, G.; Nemoto, H.; Sanada, Y.; et al. Expression levels of thymidylate synthase, dihydropyrimidine dehydrogenase, and thymidine phosphorylase in patients with colorectal cancer. Anticancer Res. 2012, 32, 1757-1762. [PubMed]

245. Lindskog, E.B.; Wettergren, Y.; Odin, E.; Gustavsson, B.; Derwinger, K. Thymidine Phosphorylase Gene Expression in Stage III Colorectal Cancer. Clin. Med. Insights Oncol. 2012, 6, 347-353. [CrossRef]

246. Sakowicz-Burkiewicz, M.; Przybyla, T.; Wesserling, M.; Bielarczyk, H.; Maciejewska, I.; Pawelczyk, T. Suppression of TWIST1 enhances the sensitivity of colon cancer cells to 5-fluorouracil. Int. J. Biochem. Cell Biol. 2016, 78, 268-278. [CrossRef]

247. Mori, R.; Yoshida, K.; Futamura, M.; Suetsugu, T.; Shizu, K.; Tanahashi, T.; Tanaka, Y.; Matsuhashi, N.; Yamaguchi, K. The inhibition of thymidine phosphorylase can reverse acquired 5FU-resistance in gastric cancer cells. Gastric Cancer 2019, 22, 497-505. [CrossRef]

248. Zizzo, N.; Passantino, G.; D’alessio, R.M.; Tinelli, A.; Lopresti, G.; Patruno, R.; Tricarico, D.; Maqoud, F.; Scala, R.; Zito, F.A.; et al. Thymidine Phosphorylase Expression and Microvascular Density Correlation Analysis in Canine Mammary Tumor: Possible Prognostic Factor in Breast Cancer. Front. Vet. Sci. 2019, 6, 368. [CrossRef]

249. Hasegawa, K.; Okamoto, H.; Kawamura, K.; Kato, R.; Kobayashi, Y.; Sekiya, T.; Udagawa, Y. The effect of chemotherapy or radiotherapy on thymidine phosphorylase and dihydropyrimidine dehydrogenase expression in cancer of the uterine cervix. Eur. J. Obstet. Gynecol. Reprod. Biol. 2012, 163, 67-70. [CrossRef]

250. Farina-Sarasqueta, A.; van Lijnschoten, G.; Rutten, H.J.T.; van den Brule, A.J.C. Value of gene polymorphisms as markers of 5-FU therapy response in stage III colon carcinoma: A pilot study. Cancer Chemother. Pharmacol. 2010, 66, 1167-1171. [CrossRef]

251. Yadak, R.; Breur, M.; Bugiani, M. Gastrointestinal Dysmotility in MNGIE: From thymidine phosphorylase enzyme deficiency to altered interstitial cells of Cajal. Orphanet J. Rare Dis. 2019, 14, 33. [CrossRef] [PubMed]

252. Falcão de Campos, C.; Oliveira Santos, M.; Roque, R.; Conceição, I.; de Carvalho, M. Mitochondrial Neurogastrointestinal Encephalomyopathy: Novel Pathogenic Mutation in Thymidine Phosphorylase Gene in a Patient from Cape Verde Islands. Case Rep. Neurol. Med. 2019, 2019, 5976410. [CrossRef] [PubMed]

253. Huang, H.; Yang, X.; Liu, L.; Xu, Y. Leukoencephalopathy in Mitochondrial Neurogastrointestinal Encephalomyopathy-Like Syndrome with Polymerase-Gamma Mutations. Ann. Indian Acad. Neurol. 2019, 22, 325-327. [CrossRef] [PubMed]

254. Filosto, M.; Cotti Piccinelli, S.; Caria, F.; Gallo Cassarino, S.; Baldelli, E.; Galvagni, A.; Volonghi, I.; Scarpelli, M.; Padovani, A. Mitochondrial Neurogastrointestinal Encephalomyopathy (MNGIE-MTDPS1). J. Clin. Med. 2018, 7, 389. [CrossRef] [PubMed]

255. Jacob, J.; Gopalan, R.; Lakshmanaperumalsamy, P.; Illuri, R.; Bhosle, D.; Sangli, G.K.; Mundkinajeddu, D. Evaluation of Antipsoriatic Potential of the Fruit Rind of Punica granatum L. Pharmacogn. J. 2019, 11, 466-468. [CrossRef]

256. Javaid, S.; Shaikh, M.; Fatima, N.; Choudhary, M.I. Natural compounds as angiogenic enzyme thymidine phosphorylase inhibitors: In vitro biochemical inhibition, mechanistic, and in silico modeling studies. PLoS ONE 2019, 14, e0225056. [CrossRef] 
257. Li, W.; Yue, H. Thymidine phosphorylase: A potential new target for treating cardiovascular disease. Trends Cardiovasc. Med. 2018, 28, 157-171. [CrossRef]

258. Warren, H.R.; Hejmadi, M. Effect of hypoxia on chemosensitivity to 5-fluorouracil in SH-SY5Y neuroblastoma cells. Biosci. Horiz. Int. J. Stud. Res. 2016, 9. [CrossRef]

259. Jing, X.; Yang, F.; Shao, C.; Wei, K.; Xie, M.; Shen, H.; Shu, Y. Role of hypoxia in cancer therapy by regulating the tumor microenvironment. Mol. Cancer 2019, 18, 157. [CrossRef]

260. Nijhuis, A.; Thompson, H.; Adam, J.; Parker, A.; Gammon, L.; Lewis, A.; Bundy, J.G.; Soga, T.; Jalaly, A.; Propper, D.; et al. Remodelling of microRNAs in colorectal cancer by hypoxia alters metabolism profiles and 5-fluorouracil resistance. Hum. Mol. Genet. 2017, 26, 1552-1564. [CrossRef]

261. Palmirotta, R.; Lovero, D.; Delacour, H.; Le Roy, A.; Cremades, S.; Silvestris, F. Rare Dihydropyrimidine Dehydrogenase Variants and Toxicity by Floropyrimidines: A Case Report. Front. Oncol. 2019, 9, 139. [CrossRef]

262. Latchman, J.; Guastella, A.; Tofthagen, C. 5-Fluorouracil toxicity and dihydropyrimidine dehydrogenase enzyme: Implications for practice. Clin. J. Oncol. Nurs. 2014, 18, 581-585. [CrossRef] [PubMed]

263. Mukherji, D.; Massih, S.A.; Tfayli, A.; Kanso, M.; Faraj, W. Three different polymorphisms of the DPYD gene associated with severe toxicity following administration of 5-FU: A case report. J. Med. Case Rep. 2019, 13, 76. [CrossRef] [PubMed]

264. Amstutz, U.; Henricks, L.M.; Offer, S.M.; Barbarino, J.; Schellens, J.H.M.; Swen, J.J.; Klein, T.E.; McLeod, H.L.; Caudle, K.E.; Diasio, R.B.; et al. Clinical Pharmacogenetics Implementation Consortium (CPIC) Guideline for Dihydropyrimidine Dehydrogenase Genotype and Fluoropyrimidine Dosing: 2017 Update. Clin. Pharmacol. Ther. 2018, 103, 210-216. [CrossRef] [PubMed]

265. Lunenburg, C.A.T.C.; van der Wouden, C.H.; Nijenhuis, M.; Crommentuijn-van Rhenen, M.H.; de Boer-Veger, N.J.; Buunk, A.M.; Houwink, E.J.F.; Mulder, H.; Rongen, G.A.; van Schaik, R.H.N.; et al. Dutch Pharmacogenetics Working Group (DPWG) guideline for the gene-drug interaction of DPYD and fluoropyrimidines. Eur. J. Hum. Genet. 2020, 28, 508-517. [CrossRef]

266. De Falco, V.; Natalicchio, M.I.; Napolitano, S.; Coppola, N.; Conzo, G.; Martinelli, E.; Zanaletti, N.; Vitale, P.; Giunta, E.F.; Vietri, M.T.; et al. A case report of a severe fluoropyrimidine-related toxicity due to an uncommon DPYD variant. Medicine 2019, 98, e15759. [CrossRef]

267. Meulendijks, D.; Henricks, L.M.; Sonke, G.S.; Deenen, M.J.; Froehlich, T.K.; Amstutz, U.; Largiader, C.R.; Jennings, B.A.; Marinaki, A.M.; Sanderson, J.D.; et al. Clinical relevance of DPYD variants c.1679T>G, c.1236G>A/HapB3, and c.1601G>A as predictors of severe fluoropyrimidine-associated toxicity: A systematic review and meta-analysis of individual patient data. Lancet. Oncol. 2015, 16, 1639-1650. [CrossRef]

268. Nie, Q.; Shrestha, S.; Tapper, E.E.; Trogstad-Isaacson, C.S.; Bouchonville, K.J.; Lee, A.M.; Wu, R.; Jerde, C.R.; Wang, Z.; Kubica, P.A.; et al. Quantitative Contribution of rs75017182 to Dihydropyrimidine Dehydrogenase mRNA Splicing and Enzyme Activity. Clin. Pharmacol. Ther. 2017, 102, 662-670. [CrossRef]

269. Sun, M.; Zhong, J.; Zhang, L.; Shi, S. Genetic impact of methylenetetrahydrofolate reductase (MTHFR) polymorphism on the susceptibility to colorectal polyps: A meta-analysis. BMC Med. Genet. 2019, 20, 94. [CrossRef]

270. Jiang, H.; Shen, Y. Methylene tetrahydrofolate reductase (MTHFR) gene rs1801133 C>T polymorphisms and response to 5-FU based chemotherapy in patients with colorectal cancer: A meta-analysis. Pteridines 2019, 30, 126-132. [CrossRef]

271. Kim, K.-R.; Yoon, J.-H.; Shim, H.-J.; Hwang, J.-E.; Bae, W.-K.; Chung, I.-J.; Kim, H.-N.; Shin, M.-H.; Cho, S.-H. Role of depth of response and MTHFR genotype as predictors of fluorouracil rechallenge therapy for refractory metastatic colorectal cancer. Oncol. Lett. 2017, 14, 2491-2498. [CrossRef] [PubMed]

272. Zawiah, M.; Yousef, A.-M.; Kadi, T.; Yousef, M.; Majdalawi, K.; Al-Yacoub, S.; Al-Hiary, R.; Tantawi, D.; Mukred, R.; Ajaj, A.R. Early disease relapse in a patient with colorectal cancer who harbors genetic variants of DPYD, TYMS, MTHFR and DHFR after treatment with 5-fluorouracil-based chemotherapy. Drug Metab. Pers. Ther. 2018, 33, 201-205. [CrossRef] [PubMed]

273. Botticelli, A.; Borro, M.; Onesti, C.E.; Strigari, L.; Gentile, G.; Cerbelli, B.; Romiti, A.; Occhipinti, M.; Sebastiani, C.; Lionetto, L.; et al. Degradation Rate of 5-Fluorouracil in Metastatic Colorectal Cancer: A New Predictive Outcome Biomarker? PLoS ONE 2016, 11, e0163105. [CrossRef] [PubMed]

274. Tsukihara, H.; Tsunekuni, K.; Takechi, T. Folic Acid-Metabolizing Enzymes Regulate the Antitumor Effect of 5-Fluoro-2'Deoxyuridine in Colorectal Cancer Cell Lines. PLoS ONE 2016, 11, e0163961. [CrossRef]

275. Okada, K.; Hakata, S.; Terashima, J.; Gamou, T.; Habano, W.; Ozawa, S. Combination of the histone deacetylase inhibitor depsipeptide and 5-fluorouracil upregulates major histocompatibility complex class II and p21 genes and activates caspase-3/7 in human colon cancer HCT-116 cells. Oncol. Rep. 2016, 36, 1875-1885. [CrossRef]

276. Terranova-Barberio, M.; Pecori, B.; Roca, M.S.; Imbimbo, S.; Bruzzese, F.; Leone, A.; Muto, P.; Delrio, P.; Avallone, A.; Budillon, A.; et al. Synergistic antitumor interaction between valproic acid, capecitabine and radiotherapy in colorectal cancer: Critical role of p53. J. Exp. Clin. Cancer Res. 2017, 36, 177. [CrossRef]

277. Sveen, A.; Bruun, J.; Eide, P.W.; Eilertsen, I.A.; Ramirez, L.; Murumägi, A.; Arjama, M.; Danielsen, S.A.; Kryeziu, K.; Elez, E.; et al. Colorectal Cancer Consensus Molecular Subtypes Translated to Preclinical Models Uncover Potentially Targetable Cancer Cell Dependencies. Clin. Cancer Res. 2018, 24, 794-806. [CrossRef]

278. Kryeziu, K.; Bruun, J.; Guren, T.K.; Sveen, A.; Lothe, R.A. Combination therapies with HSP90 inhibitors against colorectal cancer. Biochim. Biophys. Acta Rev. Cancer 2019, 1871, 240-247. [CrossRef]

279. He, S.; Smith, D.L.; Sequeira, M.; Sang, J.; Bates, R.C.; Proia, D.A. The HSP90 inhibitor ganetespib has chemosensitizer and radiosensitizer activity in colorectal cancer. Investig. New Drugs 2014, 32, 577-586. [CrossRef] 
280. Gong, S.; Xu, D.; Zhu, J.; Zou, F.; Peng, R. Efficacy of the MEK Inhibitor Cobimetinib and its Potential Application to Colorectal Cancer Cells. Cell. Physiol. Biochem. 2018, 47, 680-693. [CrossRef]

281. Varghese, V.; Magnani, L.; Harada-Shoji, N.; Mauri, F.; Szydlo, R.M.; Yao, S.; Lam, E.W.-F.; Kenny, L.M. FOXM1 modulates 5-FU resistance in colorectal cancer through regulating TYMS expression. Sci. Rep. 2019, 9, 1505. [CrossRef] [PubMed]

282. Jing, C.; Li, H.; Du, Y.; Cao, H.; Liu, S.; Wang, Z.; Ma, R.; Feng, J.; Wu, J. MEK inhibitor enhanced the antitumor effect of oxaliplatin and 5-fluorouracil in MEK1 Q56P-mutant colorectal cancer cells. Mol. Med. Rep. 2019, 19, 1092-1100. [CrossRef] [PubMed]

283. Długosz-Pokorska, A.; Pięta, M.; Janecki, T.; Janecka, A. New uracil analogs as downregulators of ABC transporters in 5fluorouracil-resistant human leukemia HL-60 cell line. Mol. Biol. Rep. 2019, 46, 5831-5839. [CrossRef] [PubMed]

284. Sunami, E.; Kusumoto, T.; Ota, M.; Sakamoto, Y.; Yoshida, K.; Tomita, N.; Maeda, A.; Teshima, J.; Okabe, M.; Tanaka, C.; et al. S-1 and Oxaliplatin Versus Tegafur-uracil and Leucovorin as Postoperative Adjuvant Chemotherapy in Patients With High-risk Stage III Colon Cancer (ACTS-CC 02): A Randomized, Open-label, Multicenter, Phase III Superiority Trial. Clin. Colorectal Cancer 2020, 19, 22-31. [CrossRef]

285. Kim, H.G.; Kim, C.W.; Lee, D.H.; Lee, J.-S.; Oh, E.-T.; Park, H.J. Quinacrine-Mediated Inhibition of Nrf2 Reverses Hypoxia-Induced 5-Fluorouracil Resistance in Colorectal Cancer. Int. J. Mol. Sci. 2019, 20, 4366. [CrossRef]

286. Nishizawa, Y.; Ikeda, R.; Yamamoto, M.; Kawahara, K.; Shinsato, Y.; Minami, K.; Nitta, M.; Terazono, H.; Akiyama, S.-I.; Furukawa, T.; et al. 5-Aza-2-deoxycytidine Enhances the Sensitivity of 5-Fluorouracil by Demethylation of the Thymidine Phosphorylase Promoter. Anticancer Res. 2019, 39, 4129-4136. [CrossRef]

287. Falcone, A.; André, T.; Edeline, J.; François, E.; Taieb, J.; Phelip, J.; Portales, F.; Price, T.; Becquart, M.; Moreno Vera, S.; et al. Safety and efficacy of trifluridine/tipiracil in previously treated metastatic colorectal cancer (mCRC): Preliminary results from the phase IIIb, international, open-label, early-access PRECONNECT study. Ann. Oncol. 2018, 29, v104-v105. [CrossRef]

288. Minegaki, T.; Suzuki, A.; Mori, M.; Tsuji, S.; Yamamoto, S.; Watanabe, A.; Tsuzuki, T.; Tsunoda, T.; Yamamoto, A.; Tsujimoto, M.; et al. Histone deacetylase inhibitors sensitize 5-fluorouracil-resistant MDA-MB-468 breast cancer cells to 5-fluorouracil. Oncol. Lett. 2018, 16, 6202-6208. [CrossRef]

289. Jang, H.Y.; Kim, D.H.; Lee, H.J.; Kim, W.D.; Kim, S.-Y.; Hwang, J.J.; Lee, S.J.; Moon, D.H. Schedule-dependent synergistic effects of 5-fluorouracil and selumetinib in KRAS or BRAF mutant colon cancer models. Biochem. Pharmacol. 2019, 160, 110-120. [CrossRef]

290. Shimada, T.; Tsuruta, M.; Hasegawa, H.; Okabayashi, K.; Shigeta, K.; Ishida, T.; Asada, Y.; Suzumura, H.; Koishikawa, K.; Akimoto, S.; et al. Heat shock protein 27 knockdown using nucleotide-based therapies enhances sensitivity to 5-FU chemotherapy in SW480 human colon cancer cells. Oncol. Rep. 2018, 39, 1119-1124. [CrossRef]

291. Lavitrano, M.; Ianzano, L.; Bonomo, S.; Cialdella, A.; Cerrito, M.G.; Pisano, F.; Missaglia, C.; Giovannoni, R.; Romano, G.; McLean, C.M.; et al. BTK inhibitors synergise with 5-FU to treat drug-resistant TP53-null colon cancers. J. Pathol. 2020, 250, 134-147. [CrossRef] [PubMed]

292. Mendoza-Rodríguez, M.G.; Sánchez-Barrera, C.Á.; Callejas, B.E.; García-Castillo, V.; Beristain-Terrazas, D.L.; Delgado-Buenrostro, N.L.; Chirino, Y.I.; León-Cabrera, S.A.; Rodríguez-Sosa, M.; Gutierrez-Cirlos, E.B.; et al. Use of STAT6 Phosphorylation Inhibitor and Trimethylglycine as New Adjuvant Therapies for 5-Fluorouracil in Colitis-Associated Tumorigenesis. Int. J. Mol. Sci. 2020, 21, 2130. [CrossRef] [PubMed]

293. Lu, C.; Klement, J.D.; Yang, D.; Albers, T.; Lebedyeva, I.O.; Waller, J.L.; Liu, K. SUV39H1 regulates human colon carcinoma apoptosis and cell cycle to promote tumor growth. Cancer Lett. 2020, 476, 87-96. [CrossRef] [PubMed]

294. Chen, S.; Yue, T.; Huang, Z.; Zhu, J.; Bu, D.; Wang, X.; Pan, Y.; Liu, Y.; Wang, P. Inhibition of hydrogen sulfide synthesis reverses acquired resistance to 5-FU through miR-215-5p-EREG/TYMS axis in colon cancer cells. Cancer Lett. 2019, 466, 49-60. [CrossRef] [PubMed]

295. Andreucci, E.; Ruzzolini, J.; Peppicelli, S.; Bianchini, F.; Laurenzana, A.; Carta, F.; Supuran, C.T.; Calorini, L. The carbonic anhydrase IX inhibitor SLC-0111 sensitises cancer cells to conventional chemotherapy. J. Enzyme Inhib. Med. Chem. 2019, 34, 117-123. [CrossRef]

296. Xi, C.; Wang, L.; Yu, J.; Ye, H.; Cao, L.; Gong, Z. Inhibition of cyclin-dependent kinases by AT7519 is effective to overcome chemoresistance in colon and cervical cancer. Biochem. Biophys. Res. Commun. 2019, 513, 589-593. [CrossRef]

297. Xi, C.; Wang, L.; Yu, J.; Ye, H.; Cao, L.; Gong, Z. Inhibition of eukaryotic translation initiation factor 4E is effective against chemo-resistance in colon and cervical cancer. Biochem. Biophys. Res. Commun. 2018, 503, 2286-2292. [CrossRef]

298. Ye, Q.; Liu, K.; Shen, Q.; Li, Q.; Hao, J.; Han, F.; Jiang, R.-W. Reversal of Multidrug Resistance in Cancer by Multi-Functional Flavonoids. Front. Oncol. 2019, 9, 487. [CrossRef]

299. Wang, Z.; Zhan, Y.; Xu, J.; Wang, Y.; Sun, M.; Chen, J.; Liang, T.; Wu, L.; Xu, K. $\beta$-Sitosterol Reverses Multidrug Resistance via BCRP Suppression by Inhibiting the p53-MDM2 Interaction in Colorectal Cancer. J. Agric. Food Chem. 2020, 68, 3850-3858. [CrossRef]

300. Kong, D.; Zhang, D.; Chu, X.; Wang, J. Schizandrin A enhances chemosensitivity of colon carcinoma cells to 5-fluorouracil through up-regulation of miR-195. Biomed. Pharmacother. 2018, 99, 176-183. [CrossRef]

301. Liu, H.; Liu, H.; Zhou, Z.; Parise, R.A.; Chu, E.; Schmitz, J.C. Herbal formula Huang Qin Ge Gen Tang enhances 5-fluorouracil antitumor activity through modulation of the E2F1/TS pathway. Cell Commun. Signal. 2018, 16, 7. [CrossRef]

302. La, X.; Zhang, L.; Li, Z.; Li, H.; Yang, Y. (-)-Epigallocatechin Gallate (EGCG) Enhances the Sensitivity of Colorectal Cancer Cells to 5-FU by Inhibiting GRP78/NF-kB/miR-155-5p/MDR1 Pathway. J. Agric. Food Chem. 2019, 67, 2510-2518. [CrossRef] 
303. Li, T.; Chen, Y.; Zhang, J.; Liu, S. LncRNA TUG1 promotes cells proliferation and inhibits cells apoptosis through regulating AURKA in epithelial ovarian cancer cells. Medicine 2018, 97, e12131. [CrossRef]

304. Yang, C.; Pan, Y.; Deng, S.P. Downregulation of lncRNA CCAT1 enhances 5-fluorouracil sensitivity in human colon cancer cells. BMC Mol. Cell Biol. 2019, 20, 9. [CrossRef]

305. Fan, H.; Zhu, J.-H.; Yao, X.-Q. Knockdown of long non-coding RNA PVT1 reverses multidrug resistance in colorectal cancer cells. Mol. Med. Rep. 2018, 17, 8309-8315. [CrossRef]

306. Xiao, Y.; Yurievich, U.A.; Yosypovych, S.V. Long noncoding RNA XIST is a prognostic factor in colorectal cancer and inhibits 5-fluorouracil-induced cell cytotoxicity through promoting thymidylate synthase expression. Oncotarget 2017, 8, 83171-83182. [CrossRef]

307. Wang, L.; Cho, K.B.; Li, Y.; Tao, G.; Xie, Z.; Guo, B. Long Noncoding RNA (lncRNA)-Mediated Competing Endogenous RNA Networks Provide Novel Potential Biomarkers and Therapeutic Targets for Colorectal Cancer. Int. J. Mol. Sci. 2019, 20, 5758. [CrossRef]

308. Wang, M.; Han, D.; Yuan, Z.; Hu, H.; Zhao, Z.; Yang, R.; Jin, Y.; Zou, C.; Chen, Y.; Wang, G.; et al. Long non-coding RNA H19 confers 5-Fu resistance in colorectal cancer by promoting SIRT1-mediated autophagy. Cell Death Dis. 2018, 9, 1149. [CrossRef]

309. LI, Q.-W.; LEI, W.; CHEN, C.; GUO, W. Recent advances of long noncoding RNAs involved in the development of multiple sclerosis. Chin. J. Nat. Med. 2020, 18, 36-46. [CrossRef]

310. Jin, S.-J.; Jin, M.-Z.; Xia, B.-R.; Jin, W.-L. Long Non-coding RNA DANCR as an Emerging Therapeutic Target in Human Cancers. Front. Oncol. 2019, 9, 1225. [CrossRef]

311. Titze-de-Almeida, S.S.; de Paula Brandão, P.R.; Faber, I.; Titze-de-Almeida, R. Leading RNA Interference Therapeutics Part 1: Silencing Hereditary Transthyretin Amyloidosis, with a Focus on Patisiran. Mol. Diagn. Ther. 2020, 24, 49-59. [CrossRef] [PubMed]

312. Wong, R.R.; Abd-Aziz, N.; Affendi, S.; Poh, C.L. Role of microRNAs in antiviral responses to dengue infection. J. Biomed. Sci. 2020, 27, 4. [CrossRef] [PubMed]

313. Hanna, J.; Hossain, G.S.; Kocerha, J. The Potential for microRNA Therapeutics and Clinical Research. Front. Genet. 2019, 10, 478. [CrossRef] [PubMed]

314. Wang, W.-T.; Han, C.; Sun, Y.-M.; Chen, T.-Q.; Chen, Y.-Q. Noncoding RNAs in cancer therapy resistance and targeted drug development. J. Hematol. Oncol. 2019, 12, 55. [CrossRef]

315. Liang, G.; Zhu, Y.; Ali, D.J.; Tian, T.; Xu, H.; Si, K.; Sun, B.; Chen, B.; Xiao, Z. Engineered exosomes for targeted co-delivery of miR-21 inhibitor and chemotherapeutics to reverse drug resistance in colon cancer. J. Nanobiotechnol. 2020, 18, 10. [CrossRef]

316. Hong, X.; Dong, T.; Yi, T.; Hu, J.; Zhang, Z.; Lin, S.; Niu, W. Impact of 5-Fu/oxaliplatin on mouse dendritic cells and synergetic effect with a colon cancer vaccine. Chin. J. Cancer Res. 2018, 30, 197-208. [CrossRef]

317. Van Der Kraak, L.; Goel, G.; Ramanan, K.; Kaltenmeier, C.; Zhang, L.; Normolle, D.P.; Freeman, G.J.; Tang, D.; Nason, K.S.; Davison, J.M.; et al. 5-Fluorouracil upregulates cell surface B7-H1 (PD-L1) expression in gastrointestinal cancers. J. Immunother. Cancer 2016, 4, 65. [CrossRef]

318. Goel, G.; Ramanan, K.; Kaltenmeier, C.; Zhang, L.; Freeman, G.J.; Normolle, D.P.; Tang, D.; Lotze, M.T. Effect of 5-fluorouracil on membranous PD-L1 expression in colon cancer cells. J. Clin. Oncol. 2016, 34, 592. [CrossRef]

319. Ieranò, C.; D’Alterio, C.; Napolitano, M.; Portella, L.; Rea, G.; Monaco, G.; Maiolino, P.; Luciano, A.; Barbieri, A.; Palma, G.; et al. Abstract 4103: Blockade of intrinsic PD-1 promotes human colon cancer cells survival, chemo resistance and in vivo tumor growth of human colon cancer cells. Cancer Res. 2019, 79, 4103. [CrossRef] 